\title{
TVRDI GRAD (CASTRUM) KAMIČAC
}

\section{Krešimir REGAN}

Leksikografski zavod Miroslav Krleža

Zagreb, Hrvatska
UDK: $725.96(497.5$ Kamičac)

DOI: $10.21857 / \mathrm{mwo} 1 \mathrm{vcj} 8 \mathrm{vy}$

Izvorni znanstveni rad

Prihvaćeno: 3. travnja 2020.

U radu se na temelju arhivskih i terenskih istraživanja prikazuju ostatci tvrdog grada (castruma) Kamičca, koji leže na strmom kamenom brdu koje se gotovo okomito uzdiže iznad lijeve obale rijeke Krke, u kanjonu Med gredama između Roškog slapa i Visovačkog jezera. U dokumentima se prvi put spominje 1345. godine kao novopodignuta utvrda velikaša Nelipića, a napušten je po padu pod osmansku vlast 1522. ili 1523.

Ključne riječi: Kamičac, tvrdi grad (castrum), velikaši Nelipići, Martinušić, Utišenić, Mišljenović, rijeka Krka, XIII. - XVI. st.

\section{UVOD}

Zahvaljujući položaju na strmom kamenom brdu koje se gotovo okomito uzdiže iznad lijeve obale kanjona rijeke Krke u kanjonu nedaleko Roškog slapa i Visovačkog jezera, srednjovjekovni Kamičac jedna je od najslikovitijih utvrda u Hrvatskoj. Zahvaljujući predaji po kojoj je on mjesto rođenja legendarnog posljednjeg samostalnog hrvatskog kralja Petra (Svačića), stradalog 1097. godine u sukobu s Mađarima na Petrovoj gori, također je i jedna od najpoznatijih srednjovjekovnih utvrda u Dalmaciji.

Mada je povijest Kamičca dobro istražena, ono što nedostaje ili dosad nije pobuđivalo pozornost istraživača jest sagledavanja problematike ove utvrde $u$ cjelini. ${ }^{1}$ Stoga nam je cilj analizom postojećih ostataka utvrde ukazati na njezinu

1 Stipan Zlatović, Topografičke crtice o starohrvatskim županijama u Dalmaciji i starim gradovima na kopnu od Velebita do Neretve, Starobrvatska prosvjeta, god. 2, sv. 3, Knin, 1896. 148 - 155; O. Petar K. BAčıć, Grad Kamičak na Krci, Jadranska vila, god. 2, br. 7, Split, 1923. 105 - 106; O. Petar K. BAčıć, Grad Kamičak na Krci, Jadranska vila, god. 2, br. 8, 118 - 120; O. Petar K. BAčıć, Grad Kamičak na Krci, Jadranska vila, god. 2, br. 9, 135 - 137; O. Petar K. BAČıć, Grad Kamičak na Krci, Jadranska vila, god. 2, br. 10, 151 - 153; O. Petar K. BAčıć, Grad Kamičak na Krci, Jadranska vila, god. 2, br. 11, 167 - 171; O. Petar K. BAčıć, Grad Kamičak na Krci, Jadranska vila, god. 2, br. 12, 184 - 187; Mate ZEKAN, Srednjovjekovne utvrde na rijeci Krki, Visovački zbornik, Visovac, 1997., 391 - 405; Ante JuRIć, Gradovi, utvrde i sakralni spomenici uz Krku i Čikolu, Skradin, 2004.; Mate ZEKAN, Utvrđeni gradovi i kule na rijeci Krki, Dalmatinska zagora nepoznata zemlja (katalog izložbe), Zagreb, 2007., 637 - 641; Mirela SLukAN-Altić, 
tipološku i geostratešku posebnost u odnosu na druge utvrde u susjedstvu, kao i na širem dalmatinskom i općenito hrvatskom prostoru. Mada smo se u izradi ovog rada oslonili i na starija istraživanja, on je nastao kao rezultat vlastitih terenskih ispitivanja postojećih ostataka te analize fotogrametrijskih snimki i tlocrta utvrde, fotografija snimljenih od strane prvih znatiželjnika u drugoj polovici XIX. st. te povijesnih veduta i planova, koji od treće četvrtine XVI. st. u kontinuitetu registriraju transformaciju Kamičca iz utvrde u ruševinu.

Osim samih materijalnih ostataka tvrdog grada, vrlo vrijedan izvor u istraživanju Kamičca diplomatska je građa. Za potrebe istraživanja pregledane su sve relevantne zbirke izvora, uključujući i one dostupne na internetskoj stranici Hungarica. ${ }^{2}$ To su Diplomatički zbornik, Listine o odnošajih izmedju južnoga slavenstva i Mletačke Republike, Árpádkori új okmánytár, Anjoukori okmánytár, Zsigmondkori oklevéltár, A Frangepán csalad okleveltara. Codex diplomaticus comitum de Frangepanibus te naposljetku Opsidio Iadrensis i Acta Croatica/Hrvatski spomenici. ${ }^{3}$ Također su pregledane karte iz kartografske i grafičke zbirke u Nacionalnoj i sveučilišnoj knjižnici, ${ }^{4}$ kartografska zbirka Hrvatskog državnog arhiva, digitalnog repozitorija HAZU, pa čak i jedna

Krka kao razdjelnica velikaških gradova Šubića i Nelipića na karti Matea Pagana nastaloj oko 1522. godine, Ekonomska i ekohistorija, god. 3, sv. 3, Zagreb-Samobor, 2007., 51 - 61; Ante BIRIN, Posjedi Nelipčića na području srednjovjekovnog kotara Promine, Miljevci u prošlosti (s pogledom u budućnost), Zbornik radova sa znanstvenog skupa Miljevci u prošlosti (s pogledom u budućnost), ur. Marko Menđušić i Drago Marguš, Visovac-Drinovci, 2008., 117- 128; Joško Zaninović, Davor Gaurina, Nelipićeve utvrde na rijekama Krki i Čikoli, Miljevci u prošlosti (s pogledom u budućnost) Zbornik radova sa znanstvenog skupa Miljevci u proślosti (s pogledom u budućnost), ur. Marko Menđušić i Drago Marguš,145- 162; Marina Ninić, Bojana Obad Šćitaroci, Damir KRAJNiK, Srednjovjekovne utvrde na području Nacionalnog parka Krka, Prostor, god. 20, sv. 2, Zagreb, 2012., 393 - 401; Krsto Sтоšı́́, Rijeka Krka sa 54 slike. Priredio i popratnu studiju napisao Drago Marguš, Šibenik, 2012.

2 https://hungaricana.hu/en/, posjećeno 18.6.2019.

3 Šime LJubić, Listine o odnošajih izmedju južnoga slavenstva i Mletačke Republike, Knj. I-X, Zagreb, 1868. -1891.; Gusztáv Wenzel, Arpádkori új okmánytár. Codex diplomaticus Arpadianus continuatus, Budapest, Vol. I-XII, Pest, 1860. - 1874.; Imre NAGY, Anjoukori okmánytár. Codex diplomaticus Hungaricus Andegavensis. I. (1301-1321), vol. I-XL, Budapest, 1878. - 2014.; Tadija Smičı knaset. al, Codex diplomaticus Regni Croatiae, Dalmatiae et Slavoniae. Diplomatički zbornik Kraljevine Hrvatske, Dalmacije i Slavonije, Vol. I-XVIII, Zagreb, 1904. - 1990.; Lajos Thallóczy, A Frangepán csalad okleveltara. Codex diplomaticus comitum de Frangepanibus, Budapest, 1910.; Elemér MÁLyuszetal., Zsigmondkori oklevéltár, vol. I-X, Budapest, 1951. 2007.; Veljko Gortan, Branimir Glavičić, Vladimir Vratović, Miroslav Kurelac, Damir Karbić, Zoran Ladić, Obsidio iadrensis/Opsada Zadra, Zagreb, 2007.; Stjepan Ivšıć, Josip BRATUlić, Zoran LADić, Acta croatica, Zagreb, 2017.

4 https://digitalna.nsk.hr/pb/?object=view\&id=10182\&tify=\{\%22pages\%22:[1],\%22view\%22:\%2 2scan\%22\}, posjećeno 18. 6. 2019. 
privatna kartografska zbirka dostupna na internetu. ${ }^{5} \mathrm{Uz}$ to je konzultirana i nedavno otkrivena karta sjeverne i srednje Dalmacije nepoznatog autora iz prve polovice XVI. stoljeća, koju su najprije objavili Hrvoje Kekez, Daria Škarpa Durbeta, Duško Čikara i Anka Ćurić u svom konzervatorskom elaboratu o Kninskoj tvrđavi, a potom Kristijan Juran, Karen-Edis Barzman i Josip Faričić. ${ }^{6}$ Nažalost, u svim navedenim izvorima pronađeno je izuzetno malo podataka o samoj utvrdi, a tek nešto više o njezinim gospodarima.

Neovisno o tome što su se od Kamičca sačuvali tek skromni ostatci, oni su u dovoljnoj mjeri očuvani da se u kombinaciji s grafičkim i fotografskim izvorima te analogijom prema sličnim kompleksima u Hrvatskoj, ali i u susjedstvu, izvrši hipotetska rekonstrukcija njegova izgleda od svog prvog spomena u izvorima u XIV. st. pa sve do propasti nakon osmanskog osvajanja u prvoj četvrtini XVI. st.

I na kraju nekoliko riječi o razlozima korištenja sintagme „tvrdi grad“ za srednjovjekovno utvrđeno prebivalište, koje se u latinskim izvorima naziva castrum. ${ }^{7} \mathrm{U}$ dosadašnjim radovima za ovu vrstu srednjovjekovnih obrambenih

5 Mirko Marković, Descriptio Croatiae. Hrvatske zemlje na geografskim kartama od najstarijih vremena do pojave topografskih karata, Zagreb, 1993.; http://www.felbar.com/hr/map/autors/a-e/ page/6/view/19/, posjećeno 18.6.2019.

6 Nažalost, na njoj su prikazi utvrda, pa tako i Kamičca, rađeni jednim od dva simbola koje nepoznati autor koristi za označavanje utvrda. Hrvoje KEKEZ, Daria ŠKARPA Durbeta, Duško Čı IKARA, Anka Ćurić Povijesna studija o razvoju kninske tvrđave, u: Knin. Kninska tvrdava. Konzervatorski elaborat, Zagreb, 2018., 73 - 74, digitalno izdanje, https://www.knin.hr/wp-content/ uploads/2019/02/Kninska-tvrdava-Elaborat_ispravak.pdf, posjećeno 18.6.2020.; Kristijan JURAN, Karen-Edis BARZMAN i Josip FARIČIĆ, Kartografija u službi mletačke države: karta sjeverne i srednje Dalmacije nepoznatog autora s početka 16. stoljeća, Geoadria, 24(2019), 2.

7 Pojam castrum se u izvorima XIII. st. koristio i za dobro utvrđena naselja, kao što je to slučaj sa zagrebačkim Gradecom. No, tijekom narednih stoljeća taj se pojam počeo isključivo odnositi na utvrđena sjedišta vlastelinstva, a usporedno s njime se od XIV. st. počeo koristiti i pojam arx. Korištenje ovog termina nije imalo isključivo vezu samo s njegovim obrambenim mogućnostima, već i s geostrateškim značenjem. Prema Damiru Karbiću, „u historiografiji nije u potpunosti utvrđeno koliko je ta razlika (nap. a. - između castruma i castelluma) bila konstantna i koliko je značila na samom terenu. Čini se da je za razlikovanje bio važniji neki vid pravnog položaja nego građevinske karakteristike i važnost.“ Damir KARBIĆ, Povijesni podaci o burgu Vrbovcu, u: Tatjana TKALČEc, Burg Vrbovec u Klenovcu Humskome, Zagreb, 2010., 214, bilj. 47. Sličan argument može se primijeniti u razlikovanju pojmova castrum od arx. Naime, pojmom arx označavaju se uglavnom vrlo snažne utvrde, nerijetko uz more (npr. Accon u Palestini). No, izvori pokazuju da nije uvijek tako, odnosno da su se arx nazivale i utvrde od iznimnog strateškog značaja. O terminima castrum, castellum i arx vidi još: Anđela Horvat, grad (burg), Enciklopedija Jugoslavije, 3. Zagreb, 1958. 525 -531; Eric FüGEDI, Castles and society in medieval Hungary (1000-1437), Budapest, $1986 . ;$ Ana DeAnović, Glosar naziva u upotrebi srednjovjekovnog i renesansnog vojnog graditeljstva u Hrvatskoj, Utvrde i perivoji, Zagreb, 2001., 79 - 96; Zsolt HunYadi, Hospitallers in the medieval Kingdom of Hungary, c. 1150-1387. (A Dissertation), Budapest, 2004.; Zsolt HunYADI, The formation of the territorial structure of the Templars and Hospitallers in the medieval Kingdom of Hungary, u: Die geistlichen Ritterorden in Mitteleuropa. Mittelalter, Brno, 2011., 183 - 197. 
kompleksa korištena je sintagma „plemićki grad“, sastavljenu od imenice grad u značenju srednjovjekovne utvrde i pridjeva plemićki prema nazivu staleža koji je najčešće podizao utvrde. Nakon što su pojedini istraživači skrenuli pozornost da su pojedine utvrde gradili vladari, crkveni veledostojnici i viteški redovi, te da se na njih ne može odnositi spomenuta sintagma jer nisu pripadali plemićkom staležu iako su bili dio vladajuće kaste, naposljetku smo se odlučili za sintagmu „tvrdi grad“ kao terminus tehnicus.

Također smo dužni osvrnuti se i na različite nazive ove utvrde kroz povijest. Ugarsko-hrvatski kralj Ludovik I. Veliki i Sigismund Luksemburgovac te Kurjakovići nazivaju je u svojim ispravama tvrdim gradom Kamičkom ili Kamičcom (castrum ...Chamichech 1345.; Kemichech 1372.; Kamicsác var 1406.; Kamičac 1489.), a njih će kasnije koristiti i većina istraživača prošlosti ove utvrde. ${ }^{8}$ S obzirom na to da se ovaj tvrdi grad u izvorima spominje pod oba naziva, prvenstvo ćemo ipak dati nazivu Kamičac iz 1489. godine kao prvim hrvatskim jezikom i glagoljicom zapisanim toponimom.

Uz te najrašireniji nazive, mletački kartograf Matteo Pagano na svom ga znamenitom zemljovidu utvrda sjeverne Dalmacije i Like naziva Ramica, ${ }^{9}$ dok na koloriranoj razglednici s početka XX. st. Kamičac nosi ime Utješinovićevi Dvori prema kardinalu Jurju Utješinoviću koji se rodio u njemu. ${ }^{10}$ Pod nazivom Utješinović grad opisuje K. Stošić u svojoj knjizi o rijeci Krki. ${ }^{11} \mathrm{Na}$ topografskim kartama Državnog geodetskog zavoda u mjerilu 1 : 25000 sami ostatci utvrde Kamičac nazivaju se Babin gradom, a predio sjeverno od njih Kamičkom, što unosi zabunu jer je Babin grad pučki naziv za ostatke utvrde Rog ili Rogovo, čiji ostatci leže na nasuprotnoj obali Krke nedaleko Kamičca. ${ }^{12}$ Ante Jurić navodi još da se Kamičac naziva i Zamišten ili Zamršten, pozivajući

8 Tadija Smičıklas (ur.), Diplomatički zbornik, 11, Zagreb, 1913., 249 - 252, dok. 192.; Tadija SMIČı k las (ur.), Diplomatički zbornik (dalje CD), 14, Zagreb, 1916., 440 - 442, dok. 329; Elemér MÁlyusz (ur.), Zsigmondkori oklevéltár, 2. Budapest, 1958., 573, dok. 4666, https://library. hungaricana.hu/hu/view/MolDigiLib_MOLkiadv2_04/?pg=0\&layout=s, posjećeno 29. 9. 2019., Stjepan Ivšić, Josip Bratulić, Zoran Ladić, Acta croatica, Zagreb, 2017., dok 122, 278; Ivan Jurković, Povijest Hrvata, knj. III, Zagreb, 2019., 344.

9 Nacionalna i sveučilišna knjižnica u Zagrebu, Zbirka Novak u Zbirci zemljovida i atlasa NSK, https://digitalna.nsk.hr/pb/ ?object=view\&id=10182\&tify=\{\%22pages\%22:[1],\%22view\%22:\%2 2scan\%22\}, posjećeno 29. 9. 2019.

10 Gradina Kamičak: razvaline Utješenovićevih Dvora kod Drniša u Dalmaciji, Nacionalna i sveučilišna knjižnica u Zagrebu, https://digitalna.nsk.hr/pb/?object=info\&id=573557, posjećeno 29. 9. 2019.

11 K. Stošić, Rijeka Krka, 48.

12 Babin grad pučki je naziv utvrde Rog ili Rogovo, koja se nalazila na suprotnoj, desnoj obali Krke nedaleko Kamička. Geoportal, https://geoportal.dgu.hr/, posjećeno 29. 9. 2019. 
se pri tome na tekst fra Petra Bačića, dok Drago Marguš u svojoj studiji spominje još i ime Orlov grad. ${ }^{13}$

\section{POVIJEST}

Za razliku od brojnih utvrda za koje ne znamo ni približno vrijeme nastanka ni njihove graditelje, kod Kamičca to nije slučaj. Mada su pojedini autori utemeljenje Kamičca povezivali s rodom Svačića, pa čak is posljednjim hrvatskim kraljem Petrom (Svačićem), ${ }^{14}$ zahvaljujući poznatom sukobu Nelipca II. Nelipića s ugarsko-hrvatskim kraljem Karlom I. Robertom, a potom s njegovim sinom Ludovikom I. Velikim, koji je okončan tek 1345. godine nagodbom između krune s Nelipićevom udovicom Vladislavom Kurjaković i sinom Ivanom II. Nelipićem, znamo da je Kamičac prije 1344. godine iznova sagradio Nelipac II. na svom nasljednom posjedu. ${ }^{15}$ Mada $u$ ispravi nije zabilježeno od kada se područje Kamičac nalazilo u rukama Nelipića, vrlo je izgledno da su posjede na lijevoj, prominskoj strani Krke Nelipići stekli tijekom posljednje četvrtine XIII. st. kao familijari knezova Bribirskih. ${ }^{16}$

Jesu li Nelipići dolaskom na Krku stekli već postojeću utvrdu ne može se na žalost ničim argumentirati, ali se isto tako ne može u potpunosti ni isključiti sudeći prema ostatcima utvrđenog palasa ili kule na najvišoj točki utvrde $s$ vrlo tankim zidovima, što je odlika upravo utvrda građenih prije provale Tatara 1240./41. godine. ${ }^{17}$ Ono što je sigurno jest da je Nelipac II. Nelipić izgradio

13 Nismo pronašli taj podatak u citiranom broju Jadranske vile. U bilješci se Ante Jurić poziva na tekst fra Petra Bačića objavljen u Jadranskoj vili br. 8, no njega na citiranom mjestu nema. A. JURIĆ: Gradovi, utvrde i sakralni spomenici, 117, bilješka 2; D. MAGAš, Rijeka Krka sa 108 slika, u: K. STošı́́, Rijeka Krka, 62.

14 P. K. BAČIĆ, Grad Kamičak na Krci, br. 7, 105 - 106; P. K. BAčıć, Grad Kamičak na Krci, br. 8, 118 - 120; P. K. BAčıć, Grad Kamičak na Krci, br. 9, 135 - 137; P. K. BAČıć, Grad Kamičak na Krci, br. $12,184-187$.

15 „[...] preterea castrum suum hereditarium Chamichech vocatum, qoud super sua possessione hereditaria de nouo constructum habetur, cum suis possessionibus vniuersis hereditariis, tamquam ius suum hereditarium sibi et suis heredibus perpetuo tenere et habere confirmamus." Tadija SMIČI KLAS (ur.), Diplomatički zbornik, 11, Zagreb, 1913., 249 - 252, dok. 192.

16 Stjepan GunjačA, Ispravci i dopune starijoj hrvatskoj historiji, sv. 4, Zagreb, 1978., 27 - 28 ; A. Birin, Knez Nelipac, 16 - 21; A. Birin, Posjedi Nelipčića na području srednjovjekovnog kotara Promine, 117 - 118.

17 Analogijom prema bedemima Grebengrada, Hreljina, Ledenica, Malog Kalnika, Mogorića, Ostrovice Ličke, Ozlja, Krbave i Okića, koji iznose od 0,55 do 0,9 m, Zorislav Horvat zaključio je da predtatarske utvrde nisu imale debele bedeme, za razliku od utvrda nastalih poslije provale Tatara 1240./41. Jedan od razloga leži u činjenici da su graditelji tih najstarijih utvrda spretno koristili teško pristupačne položaje zbog čega nije ni bilo potrebe za gradnjom debelih i visokih bedema. Zorislav HoRvAT, Burgologija - Srednjovjekovni utvrdeni gradovi kontinentalne Hrvatske, Zagreb, 2014., 107 - 109. 
novu utvrdu na svom nasljednom posjedu što potvrđuje i Ludovikova isprava iz 1345. godine izdana njegovu sinu Ivanu II. ${ }^{18}$

Kada je Nelipićev sin Ivan II. postao cetinskim ili sinjskim knezom, upravu nad obiteljskim posjedima na lijevoj obali Krke preuzeo je njegov rođak Konstantin II. od sporedne, Izanove grane Nelipića. ${ }^{19} \mathrm{Za}$ njihove uprave obiteljski su se posjedi uz Krku našli u sklopu Kninske županije kao okrug Promina. ${ }^{20}$ Nakon što je 1396. godine preminuo Nelipac od Nečvena, posljednji muški potomak Izanove grane, sve obiteljske posjede uz Krku preuzeo je cetinski knez Ivaniš Nelipić. ${ }^{21}$

Ivaniš nije imao muškog potomka. Zbog toga su svi obiteljski posjedi poslije njegove smrti trebali pripasti Kruni. U nastojanju da izigra zakon, Ivaniš je sustavno pokušao osigurati nasljedstvo svojoj kćeri Katarini, supruzi Ivana VI. st. Frankopana. Iako se Ivaniš služio raznim pravnim smicalicama ne bi li osigurao svojoj kćeri nasljedstvo obiteljskih posjeda, ${ }^{22}$ nakon Ivaniševe smrti 1435. godine ugarsko-hrvatski kralj Sigismund Luksemburgovac zatražio je od Katarine i Ivana VI. st. Frankopana da mu predaju sve Ivaniševe posjede..$^{23}$

Kada je 1436. godine, Ivan VI. st. odbio Sigismundu predati Nelipićevu baštinu, ${ }^{24}$ Sigismund ga je proglasio nevjernikom te na njega uputio Matka i Franka Talovca da oružano zauzmu sporne posjede. Čini se da se akcija

18 Tadija Smičiklas (ur.), Diplomatički zbornik, 11, Zagreb, 1913., 249 - 252, dok. 192; A. BIRIN, Knez Nelipac, 210.

19 Ante Birin, Knez Nelipac i hrvatski velikaški rod Nelipčića, doktorski rad, Zagreb, 2006., 157 - 165. Prema Bačiću, Kamičac je počeo graditi oko 1330. godine Izan iz sporedne grane Nelišića, a dovršio njegov sin Konstantin od Nečvena. P. K. BAčıć, Grad Kamičak na Krci, br. 11, 167.

20 „Kemichech in districtu Oprominye iuxta fluvium Kerka in regno nostro Croatiae“. Tadija SMIČı Llas (ur.), Diplomatički zbornik, 14, Zagreb, 1916., 440 - 442, dok. 329.

21 A. Birin, Knez Nelipac, 157 - 165.

22 Godine 1411. Ivaniš je u ime miraza ustupio Katarini sve svoje posjede. Godine 1421. posinio je njezina supruga Ivana VI. st. Frankopana, a 1422. godine ostavio je Katarini i Ivanu ponovno sva svoja imanja, da bi 1428. svojoj kćeri fiktivno založio svoje utvrde Kamičak, Ključ i kotar Petrovo polje. Ferdo Šıšić, Iz arkiva u Željeznom, reg. XIII., 170; Lajos Thalloczy, Samu BARBÁAS, $A$ Frangepán csalad okleveltara. Codex diplomaticus comitum de Frangepanibus, Budapest, 1910. dok. CCXXXIX, 211 - 213; L. Thalloczy, S. BARBÁAs, A Frangepán csalad okleveltara. Codex diplomaticus comitum de Frangepanibus, dok. CCXL, 213; L. Thalloczy, S. Barbáas, $A$ Frangepán csalad okleveltara. Codex diplomaticus comitum de Frangepanibus, dok CCXLI, 213 215, L. Thalloczy, S. BarbáAs, A Frangepán csalad okleveltara. Codex diplomaticus comitum de Frangepanibus, CCXLIV, 225 -226; A. Birin, Posjedi Nelipčića, 125 - 126.

23 Vjekoslav Klaić, Krčki knezovi Frankapani, Zagreb,1901., 224 - 226; Petar Strečı́́, Frankapan, Ivan VI. st., Hrvatski biografski leksikon, sv. 4, Zagreb, 1998., 410 - 411.

24 P. STRČIĆ, Frankapan, Ivan VI. st., 410 - 411; Ivan MužIĆ (prir.), Vlasi u hrvatskoj historiografiji, Split, 2010., 24 - 26; Krešimir Regan, Vlatka DugačKI, Rod Talovaca ili Talovačkih i njihova ostavština u Bjelovarsko-bilogorskoj županiji, Radovi Zavoda za znanstvenoistraživački i umjetnički rad u Bjelovaru, sv. 12, Bjelovar, 2018., 143 - 144. 
odvijala tijekom studenog i prosinca 1436. kada su braća Talovci opsjeli Sinj te ga uz teške žrtve osvojili, a završila je pobjedom Talovaca 31. I. 1437. nakon Ivanove smrti, kada je njegova udovica Katarina Nelipić dobrovoljno predala Talovcima čitavu nekadašnju baštinu svoga oca Ivaniša Nelipića. ${ }^{25}$

U rukama Talovaca Kamičac je bio kraće vrijeme jer su ga po kraljevu nalogu morali prepustiti plemićkoj obitelji Martinušić. Kada se oko 1445. Ana Martinušić udala za kninskog plemića Grgura Utišenića (Utješinovića) od roda Lapčana, ova je utvrda ponovno promijenila gospodara. ${ }^{26} \mathrm{Od}$ tada njegovi gospodari Utišenići nose plemićki pridjevak „od Kamičca“. Čini se da je Grgur bio brat Matijice te stric Bartola, ličkog plemića, koji se 1469. navodi pod pridjevkom „od Kamičca“. ${ }^{27}$

Dok se još 1489. godine kao gospodar Kamičca navodi Bartulov sin Frančisko Utišenić od Kamičca, kojemu krbavski knezovi Miklovuš, Petar, Juraj i Mikula daruju jedan mlin, četiri ždrijeba zemlje, sjenkoše i četiri vrta za vjernu službu, ${ }^{28}$ već iduće se godine na krunidbi češkog kralja Vladislava II. Jagelovića za novog ugarsko-hrvatskog kralja kao gospodari utvrde spominju braća Hlapčić od Kamičca. ${ }^{29} \mathrm{~S}$ obzirom na to da je iste godine Juraj Utišenić otišao na dvor Ivaniša Korvina kao njegov štićenik, moguće je da su po smrti ugarsko-hrvatskog kralja Matije Korvina 1490. godine plemići Utišenići od Kamičca stali na stranu njegova sina Ivaniša Korvina u borbi za prijestolje zbog čega ih je novi kralj kaznio oduzimanjem njihovih imanja.

Kako bilo da bilo, Kamičac nije dugo bio u rukama Hlapčića. Njih su iz te utvrde u nepoznatim okolnostima zamijenili Mišljenovići od roda Kolunića, ${ }^{30}$

25 Sam Sinj su braća Matko i Perko zauzela tijekom studenog ili prosinca 1436. nakon žestokih borbi. Nakon predaje Matko Talovac je Ivanovu udovicu Katarinu Nelipić i malodobnog sina Jurja Frankopana po kraljevu nalogu sproveo u Modruš, gdje im je dodijelio Modrušku županiju s utvrdama Tržcem iznad Modruša i Vitunjem. Vjekoslav Klaić, Povijest Hrvata, 3. Zagreb, 1980. 160; Dubravko Lovrenović, Na klizištu povijesti, Zagreb-Sarajevo, 2006., 263; Ljubomir GUDELJ, Čačvina utvrda, Split-Trilj, 2006., 7 - 10; Ivan Mužıć, Vlasi u hrvatskoj historiografiji, Split, 2010., 25; Ivan BoticA, Krbavski knezovi u srednjem vijeku, doktorski rad, Zagreb, 2011., 207.

26 Emil Laszowski, Prilog historiji hrvatskih porodica Martinuševića, Utješinovića, Mišljenovića i njihovih srodnika, Vjesnik Kr. državnog arkiva u Zagrebu, br. 7, Zagreb, 1937., 156; Aleksandar KolArić, Juraj Utješinović i njegovo doba, Zbornik odsjeka za povijesne znanosti Zavoda za povijesne $i$ društvene znanosti HAZU, sv. 16, Zagreb, 1998., 121; Josip BRATULIĆ, Zoran LADIĆ, Acta Croatica/Hrvatski spomenici, Zagreb, 2016., 189, isp. 80; 278, isp. 122 i 365, isp. 157.

27 J. Bratulić, Z. Ladić, Acta Croatica, 189, isp. 80.

28 J. Bratulić, Z. Ladić, Acta Croatica, 278, isp. 122.

29 Ivan KunuljevićSa kcinski, Priorat Vranski sa vitezi templari $i$ hospitalci sv. Ivana u Hrvatskoj. Povijesna rasprava (rukopis), Zagreb, 1885.; M. ZEKAN, Srednjovjekovne utvrde na rijeci Krki, 401.

30 Prema Laszowskom, Mišljenovići od Kamička pripadali su rodu Šubića. E. LAszowsKI, Prilog historiji hrvatskih porodica Martinuševića, Utješinovića, Mišljenovića i njihovih srodnika, 156. 
po svoj prilici rođaci Utišinovića. ${ }^{31}$ Najpoznatiji predstavnici ove obitelji bili su hrvatski ban Marko Horvat od Kamičca, znan još i kao Marko Mišljenović od Uzdolja, koji je u ovoj utvrdi preminuo 1512. godine od rana zadobivenih u sukobu s Osmanlijama u Lici, te kninski biskup i banski namjesnik Andrija. ${ }^{32}$ Nakon Markove smrti 1512. godine, Kamičac je naslijedio njegov brat Juraj. On ga je držao do 1522. ili 1523. godine kada su ga osvojili i spalili Osmanlije. ${ }^{33}$ Unatoč tomu što su njegovi nasljednici izgubili svoju utvrdu, uspomenu na nju oni su održali u svojoj plemićkoj tituli. ${ }^{34} \mathrm{Od}$ tada pa sve do 2001. godine Kamičac je propadao. Tada je izvedeno raščišćavanje ruševina utvrda uz istovremenu izradu arhitektonskih skica ostataka utvrde. ${ }^{35}$

\section{SLIKOVNI IZVORI}

U istraživanju srednjovjekovnih tvrdih gradova, osobito njihova građevinskog razvoja, vrlo važnu ulogu imaju raznovrsni slikovni izvori, neovisno o tome jesu li perspektivni (vedute) ili tlocrtni (planovi). To je slučaj i s Kamičcom, koji se u prvoj četvrtini XVI. st. našao na prvoj liniji obrane Hrvatske prema Osmanskom Carstvu. Zbog toga je Kamičac nakratko stekao iznimno geostrateško značenje i postao predmetom interesa mletačkog kartografa Matea Pagana, koji je njegov stilizirani prikaz pod imenom Ramica uvrstio na svoj znameniti zemljovid utvrda sjeverne Dalmacije i Like iz 1522. godine, tiskan u Veneciji pod naslovom Tuto el Cotado di Zara e Sebenicho / Mateo Paganoal. ${ }^{36}$

31 S obzirom na to da se Juraj Mišljenović od Kamičca kasnije spominje kao dvorjanik kardinala Jurja Utješinovića, vrlo je izgledno da su ove dvije obitelji bile u srodstvu. E. LAszowski, Prilog historiji hrvatskih porodica Martinuševića, Utješinovića, Mišljenovića i njihovih srodnika, 156; Ivan JUR Ković, Osmanska ugroza, plemeniti raseljenici i hrvatski identitet, Povijesni prilozi, br. 31, Zagreb, 2006., 49, bilj. 33; 64, bilj. 88.

32 P. K. BAČIĆ, Grad Kamičak na Krci, br. 12, 187; Mile Bogović, Andrija, Hrvatski biografski leksikon, br. 1, Zagreb, 1983., 138 - 139; Stjepan Antolja K, Balassa, Franjo de Gyarmáth, Hrvatski biografski leksikon, br. 1, Zagreb, 1983., 382; A. JURIĆ, Gradovi, utvrde i sakralni spomenici, 122 123; Ozren BlaGeC, Slavonski i hrvatski sabori u Križevcima, Cris, god. 14, br. 1, Križevci, 2012., 369., bilješka 32 .

33 P. K. BAČIĆ, Grad Kamičak na Krci, br. 12, 186; A. JuRIĆ, Gradovi, utvrde i sakralni spomenici, 121.

34 Od 1565. do 1571. u izvorima se spominje Stjepan Mišljenović od Kamičca. E. LAszows Ki, Prilog historiji hrvatskih porodica Martinuševića, Utješinovića, Mišljenovića i njihovih srodnika,156.

35 M. Ninić, B. Obad Šćitaroci, D. Krajnik, Srednjovjekovne utvrde na području Nacionalnog parka Krka, 396.

36 Paganova karta sjeverne Dalmacije i većeg dijela Like od izuzetne je važnosti kao izvor za istraživanje tvrdih gradova u Hrvatskoj. O tome više u: Damir MAGAš, Geografske odrednice nastanka karte Matea Pagana: Cijeli okrug Zadra i Šibenika (Tutto el Contado di Zara et Sebenicho), u: Triplex Confinium (1500. - 1800.): ekohistorija: zbornik radova s medunarodnog znanstvenog skupa, ur. D. Roksandić, Split, Zagreb, 2003., 13 - 28. Nacionalna i sveučilišna knjižnica u Zagrebu (dalje 
Crtežom Kamičca dominira velika četverokutna kula, a u njezinoj pozadini prikazan je središnji dio, odnosno jezgra utvrde koju čine dva obrambena zida te još jedna visoka kula iza njih. Iako Paganov prikaz Kamičca na prvi pogled djeluje kao da je nacrtan bez uporišta u stvarnom stanju, odnosno slobodnim umjetničkim stilom, usporedimo li taj crtež s njegovim ostatcima na terenu odmah upada u oči da je Pagano prikazao Kamičac u pogledu s jugozapada i da je prostorni raspored i smještaj glavnih dijelova utvrde danas poznatih građevina manje-više pogođen. S obzirom na ranija istraživanja, koja su na primjerima Udbine, Ražanca, Kegaljgrada, Knina, Zadra i Vrane pokazala da se Pagano prilikom izrade svog zemljovida služio terenskim skicama i opisima spomenutih utvrda, vrlo je velika vjerojatnost da je crtež Kamičca precizan i u prikazu pojedinih detalja, poput visine bedema, broja kula i drugih detalja. ${ }^{37}$

NSK), Zbirka Novak u Zbirci zemljovida i atlasa NSK, https://www.bib.irb.hr/218200, posjećeno 29. 9. 2019. O značaju Paganova zemljovida za istraživanje hrvatske fortifikacijske baštine značaju Paganova zemljovida za istraživanje hrvatske fortifikacijske baštine dodatno vidjeti u: Ivo Petricioli, Novi rezultati u istraživanju zadarskih srednjovjekovnih fortifikacija, Diadora, sv. 3 , Zadar, 1965., 169 - 204; Ivo Petricioli, Zoranićeve deželije na jednoj suvremenoj karti, Zadarska revija, br. 5, Zadar, 1969, 523 - 529; Tomislav Raukar, Ivo Petricioli, Franjo Švelec, Šime PeričIĆ, Zadar pod mletačkom upravom, Zadar, 1987.; Ivo Petricioli, Stari Zadar, u slici i riječi, Zadar, 1999.; Stipe GunJAČA, Tiniensia archaeologica-historica-topographica, Starohrvatska prosvjeta, III. serija, br. 7, Split, 1960., 7 - 142; Nikola JAKšıć, Iz srednjovjekovne topografije Knina, Radovi Filozofskog fakulteta u Zadru, br. 20(9), Zadar, 1980. - 1981., 43 - 52: Franjo Smiljanić, Nastanak i razvoj srednjovjekovnog Knina, Radovi Filozofskog fakulteta u Zadru, br. 24(11), Zadar, 1984- 1985., 119 - 132; Nikola JAKšıć, Prilozi urbanizmu srednjovjekovnog Knina, Izdanja HAD-a, br.15, Zagreb, 1990., 122 - 130; Paško PAIć, Hrvatski kraljevski grad Knin, Šibenik, 1998.; Emil Hilje, Gradnja kaštela u Ražancu 1507. godine, Radovi Zavoda za povijesne znanosti u HAZU u Zadru, br. 50, Zadar, 2008., 119 - 145; Emil HiLje, Mletački kaštel u Zadru, Ars Adriatica, br. 1, Zadar, 2011., 109 - 116; Josip ĆuZELA, Šibenski fortifikacijski sustav, Šibenik, 2005.; Zorislav Horvat, Katedrala Sv. Jakova u Krbavi kraj Udbine, u: Krbavska bitka i njezine posljedice (Zbornik radova), Zagreb, 1997., 157 - 158; Mirela SLU KAN Altić, Kartografski izvori za povijest Triplex Confiniuma, Zagreb, 1999.; Mirela Slukan Altić, Razvoj gradova oko rijeke Krke, Grada i prilozi za povijest Dalmacije, 21, 2006., 21; Mirela Slukan Altić, Povijesna geografija rijeke Krke. Kartografska svjedočanstva, Šibenik, 2007.; Mirela Slukan Altić, Krka kao razdjelnica velikaških gradova Šubića i Nelipića na karti Matea Pagana nastaloj oko 1522. godine, Ekonomska i ekohistorija. Časopis za gospodarsku povijest i povijest okoliša, br. 3, Zagreb, 2007., $51-61$.

https://digitalna.nsk.hr/pb/?object=view\&id=10182\&tify=\{\%22pages\%22:[1],\%22view\%22:\%2 2scan\%22\}, posjećeno 18.6. 2019.

37 Zorislav Horvat, Katedrala sv. Jakova u Krbavi kraj Udbine, u: Krbavska bitka i njezine posljedice, Zbornik radova, ur. Dragutin Pavličević, Zagreb, 1997., 157 - 158; Ivo Petricioli, Stari Zadar u slici i riječi, Zadar, 1999., 18, 22 - 23; Mirela Slukan, Kartografski izvori za povijest Triplex Confiniuma, Zagreb, 1999., prilog 2; Mirela Slukan-Altić, Povijesna geografija rijeke Krke Kartografska svjedočanstva, Zagreb, 2007., 24 - 32; Emil HiljE, Gradnja kaštela u Ražancu 1507. godine,119 - 145; Krešimir Regan, Plemićki grad Kegalj (Kegaljgrad), Radovi Zavoda za povijesne znanosti HAZU u Zadru, sv. 54, Zadar, 2012., 1 - 34; Krešimir REGAN, Gornji grad kninske tvrđave, u: Ascendere historiam. Zbornik u čast Milana Kruheka, ur. Marija Karbić i ostali, Zagreb, 2014., 463 - 495; Krešimir RegAN, Plemićki grad Vrana, u: Braća Vranjani i vransko područje tijekom povijesti, Zbornik radova, ur. Božo Došen, Zadar, 2017., 313 - 360. 
Vrlo vrijedne podatke o izgledu Kamičca prije urušavanja većeg dijela njegovih zidova daje nam znatno mlađa grafika ostataka utvrde moguće $s$ početka XIX. st., objavljena 1880. u Radovima JAZU kao ilustracija članka o kardinalu Jurju Utješinoviću. ${ }^{38}$ Kao i na Paganovu zemljovidu, Kamičac je nacrtan u pogledu s jugozapada. Čitavim prikazom dominira manja četverokutna kula na jednom kraju kamenog brda i velika jezgra nepravilno kružnog oblika u drugom planu, također na vrhu kamenog brda. Osim što nam jasno prikazuje dvije najvažnije sastavnice ovog fortifikacijskog kompleksa, ovaj je prikaz posebno zanimljiv zbog detalja. Na prvom mjestu riječ je prikazu ostataka prsobrana s kruništem, kao i na Paganovu crtežu. Drugi važan detalj ostatci su lukova na unutrašnjem pročelju sjeveroistočnog bedema jezgre, koji nam sugeriraju postojanje obrambene staze uz bedeme, kakve nalazimo na istarskom Motovunu, ili prikazuju ostatke svodova građevine koja se nalazila unutar bedema jezgre. ${ }^{39}$

Za razliku od fotografija drugih utvrda, na kojima su njihovi ostatci vidljivi u znatno boljem stupnju uščuvanosti nego danas, kod Kamička to nije slučaj. Upravo suprotno, one nam svjedoče da je okolno stanovništvo između poč. XIX. st. i poč. XX. st. u velikoj mjeri devastiralo utvrdu.

\section{ARHITEKTURA}

Kamičac je sagrađen na vrhu iznimno stjenovitog brda, koji se strmo izdiže iznad lijeve obale rijeke Krke, između ulaza u kanjon Među gredama i Roškog slapa. Zbog njegova položaja dio autora drži da je po tome dobio ime. ${ }^{40}$ Pristup ostatcima utvrde moguć je brodom od Visovačkog jezera ili pješačkom stazom iz pravca miljevačkog sela Brištana. Do ruševina na vrhu kamenog brda vodi s jugoistočne strane uska staza dijelom uklesana u živi kamen. To je ujedno jedini mogući pravac za popeti se do utvrde jer se s preostale tri strane litice brda gotovo okomito obrušavaju prema njegovu podnožju. Od podnožja kamenog brda vodi prema utvrdi uska staza dijelom uklesana u jugoistočnu padinu brda. 
Konfiguracija tla na kojemu je podignut Kamičac uvjetovala je visinski razvedenu kompoziciju, tako da razlika između najvišeg i najnižeg dijela utvrde iznosi gotovo dvanaest metara. Dojam razvedenosti po visini dodatno nam pojačavaju ostatci zidane jezgre, koja je u izvornoj visini morala svojim volumenom biti najistaknutiji dio cijele utvrde, što nam posredno svjedoči Paganov crtež.

Prilagođena brdu na kojem leži, utvrda se pruža od sjeveroistoka prema jugozapadu u dužini od približno $52 \mathrm{~m}$, a najveća joj je širina oko $21 \mathrm{~m}$ na sjeveroistočnoj strani kompleksa. Sam vrh brda na kojem leže ostatci ove utvrde je zaravan približno trapezaste osnove, koja se u smjeru jugozapada naglo sužava u dugački i uskih hrbat brda omeđen s jugozapadne strane skromnim ostatcima pravokutne kule. Morfologija terena na kojemu je Kamičac podignut uvjetovao je njegov dugačak i uzak tlocrt u obliku ključa te podjelu na dva djela: jezgru i utvrđeno predgrađe.

\section{Jezgra}

Jezgra Kamičca najdojmljivija je cjelina čitavog kompleksa. Njezini ostatci zapremaju gotovo čitavu sjeveroistočnu polovicu utvrde, a od utvrđenog predgrađa odvojena je snažnim južnim bedemom $s$ vratima. Ima oblik nepravilnog paralelograma sa zaobljenim uglovima, dugačkog $24 \mathrm{~m}$ i širokog 21 m. Sudeći po vidljivim strukturama, jezgra se sastojala od manjeg unutrašnjeg dvorišta te višerazinskog palasa u sjeveroistočnoj polovici oslonjenog punom dužinom na sjeveroistočni bedem jezgre.

Dok se od sjeverozapadnih bedema jezgre nisu očuvali nikakvi ostatci izuzev u kamen uklesanih trakastih temelja, sa sjeveroistočne, istočne i jugoistočne strane u cijelosti su vidljive donje zone nekadašnjih bedema u cijelosti naslonjenih na kameni živac s lijepo izvedenim vanjskim licem. Zbog pada terena bedemi nisu očuvani u podjednakoj visini. Dok su ostatci jugozapadnog bedema visoki približno $1,65 \mathrm{~m}$, na jugoistočnoj strani bedemi su s vanjskim licem sačuvani u visinu od preko 4 metra. Širina bedema također varira od približno $1 \mathrm{~m}$ na istočnoj strani do čak $3 \mathrm{~m}$ na jugozapadnoj strani odakle je pristup jezgri najlakši.

$\mathrm{Na}$ jugozapadnom bedemu nalazila su se vrata u jezgru od kojih su se očuvali tek obrisi u temeljnoj zoni. Unatoč slaboj očuvanosti, možemo ih opisati kao jednostavan otvor u bedemu sa skošenim bočnim stranicama. Dok je s vanjske strane otvor bio širok oko $2 \mathrm{~m}$, s unutrašnje strane njegova je širina iznosila čak $3 \mathrm{~m}$. Sama vrata uzdignuta su za $1,65 \mathrm{~m}$ od dvorišta utvrđenog predgrađa. $S$ obzirom na konfiguraciju terena i skučenost prostora ispred nekadašnjih vrata, 
na temelju analogija možemo pretpostaviti da im se nije pristupalo pokretnim mostovima, već preko podesta koji je ležao na drvenim konstrukcijama. ${ }^{41}$

Svi bedemi jezgre Kamičca sagrađeni su od rustičnije priklesanog kamena kvadratnog formata slaganog u pravilno uslojene redove različitih visina. Pri temeljima jezgre prevladavaju veći komadi kamena, s visinom se njihove dimenzije postupno smanjuju, da bi pri vrhu oni bili znatno manji od onih pri temeljenoj zoni. S obzirom na način izvedbe plohe pročelja i vladarsku ispravu iz 1345. godine, gradnju jezgre Kamičca možemo okvirno datirati u prvu polovicu XIV. st. ${ }^{42}$ Sudeći prema postojećim ostatcima, Paganovu crtežu iz XVI. st. i grafici iz XIX. st., na vrhu bedema nalazilo se branište. S obzirom na veliku širinu bedema, nema sumnje da su stražarska staza i prsobran s kruništem i zupcima bili u cijelosti izvedeni na njima, bez konzolne drvene galerije.

$\mathrm{Na}$ najvišoj točki jezgre očuvani su zidovi manje građevine izduženog i trapezastog tlocrta, vrlo izgledno ostatci nekadašnjeg palasa. Pravcem sjeveroistok-jugozapad ova je građevina široka od 6 do $10 \mathrm{~m}$, dok je od jugoistoka prema sjeverozapada sačuvana u dužinu od desetak metara. Debljina njezinih zidova iznosi u prosjeku oko $1 \mathrm{~m}$, osim u južnom uglu gdje je njihova širina oko $1,5 \mathrm{~m}$. Vrlo je izgledno da je ova građevina izvorno imala veću dužinu, no bez arheoloških istraživanja teško je nešto više reći o njoj.

Jedini podatak o njoj daje nam Pagano, koji je prikazuje kao visoku kulu s kruništem na vrhu, dok nam crtež dvaju lukova na sjeveroistočnoj strani jezgre na slici iz XIX. st. sugeriraju da je prizemlje ove građevine bilo nadsvođeno. Uz

41 Povišeni ulazi uobičajena su pojava na srednjovjekovnim utvrdama jer se njima onemogućavala izravna neprijateljska navala. Nalazimo ih kod plemićkog grada Pake, Vrbovca kraj Huma na Sutli ili zagrebačkog Gradeca (ulaz na istočnom obrambenom zidu kraj Popova tornja). Zorislav HoRvaT, Ulazi u burgove, 12 - 15. stoljeća, Prostor, god. 6, sv. 1-2, Zagreb, 1998., 48; Marina ŠımeK, Utvrda Paka, Hrvatski arheološki godišnjak, sv. 4, Zagreb, 2007., 161 - 163; Zorislav HoRvat, Tatjana TKALČEC, Arhitektura i arhitektonska plastika burga Vrbovca kraj Huma na Sutli, Prilozi Instituta za arheologiju u Zagrebu, sv. 1, Zagreb, 2010., 181 - 218; Krešimir RegAN, Plemićki grad Garić, Radovi Zavoda za znanstvenoistraživački i umjetnički rad u Bjelovaru, sv. 4, Bjelovar, 2011., 37, bilj. 94.

42 Slične fakture zida nalazimo na bedemima Citadele Starog Grada kraj Paga iz druge pol. XIV. st., utvrde Sv. Jurja iznad Caske, Gornjem gradu Kninske tvrđave, Mletačkom kaštelu u Zadru, Prološcu kraj Imotskog iz XIV. st., Slunju iz XIV. st., na glavnoj kuli i bedemima Vrane, kao i na fragmentu zadarskog gradskog bedema uz Kapetanovu kulu. Zorislav HorvaT, O izgledu srednjovjekovnoga zida na primjerima nekih građevina u kontinentalnoj Hrvatskoj, Godišnjak zaštite spomenika kulture Hrvatske, sv. 12, Zagreb, 1986., 176 - 192; Ivo Petricioli, Novi rezultati u istraživanju zadarskih srednjovjekovnih fortifikacija, Diadora, sv. 3, Zadar, 1965., 169 - 203; Krešimir REgaN, Utvrda Sv. Jurja u Caski na otoku Pagu, Prilozi Instituta ta arheologiju u Zagrebu, sv. 19, Zagreb, 2002., 141 - 148; Emil Hilje, Mletački kaštel u Zadru, 109 - 116; Emil Hilje, Gradnja kaštela u Ražancu 1507. godine, 119 - 145; Krešimir Regan, Plemićki grad Kegalj (Kegaljgrad), 1 - 34; Krešimir RegaN, Gornji grad kninske tvrđave, 463 - 495; Krešimir Regan, Plemićki grad Vrana, 313 - 360; Z. Horvat, Burgologija. 79. 
prizemlje ova je kula svakako imala još najmanje jednu stambenu etažu i iznad nje obrambenu etažu omeđenu prsobranom s kruništem. Jeli ova građevina bila pokrivena kosim krovom ili ravnom terasom, na temelju postojećih ostataka i izvora ne može se utvrditi. Analogijom prema sličnim kompleksima u Dalmaciji, izglednije je da je ova građevina imala kupolasti završetak na koji se potom oslanjala ravna terasa. ${ }^{43}$

\section{Utvrdeno predgrade}

Za razliku od jezgre, utvrđeno predgrađe gotovo da uopće nije očuvano. No njegov osnovni oblik prepoznajemo zahvaljujući konfiguraciji terena i nekoliko skromnih fragmenata bedema. To je bila manja obrambena cjelina koja se pružala od jezgre na sjeveroistoku do pravokutne kule na jugozapadu u dužinu od $28 \mathrm{~m}$, dok mu je najveća širina iznosila prosječno $8 \mathrm{~m}$. Sastojalo se od ugaone kule na jugozapadnom kraju utvrde te dugačkog i uskog dvorišta, koje se formiralo na prostoru između kule i jezgre. Sudeći prema postojećim ostatcima i morfologiji terena, dvorište je vrlo vjerojatno bilo utvrđeno samo prema jugoistočnoj strani, dok prema sjeverozapadu nije bilo potrebe za podizanjem bedema jer tu stranu utvrde branila strma litica. $S$ obzirom na to da su se od bedema predgrađa očuvali tek skromni fragmenti te dijelom njihov temelj uklesan u kameni živac, teško je nešto više reći o njemu. Ipak možemo pretpostaviti njegovu manju visinu jer je bio podignut po samom rubu dvorišta, neposredno iznad strmih padina koje su mu davale dodatnu sigurnost. ${ }^{44}$

Najbolje očuvana građevina predgrađa ugaona je kula pravokutnog tlocrta. Nalazi se u samom jugozapadnom vrhu predgrađa, neposredno iznad strme provalije. Riječ je o masivno zidanoj građevini blago trapezastog tlocrta užom stranom okrenutom u smjeru sjeveroistoka. Bila je široka $8,3 \mathrm{~m}$ i približno jednako dugačka. Najbolje se očuvala njezina jugozapadna stranica u visinu od 3,27 m, a sve do početka XIX. st. njezini su bedemi bili očuvani gotovo do visine braništa. $S$ obzirom na to da je prosječna debljina bedema kule iznosila $1 \mathrm{~m}$ na jugozapadnoj te $2 \mathrm{~m}$ na sjeverozapadnoj i jugoistočnoj strani, dimenzije njezine unutrašnjosti relativno su skromnih 4,3 x 4,5 m.

43 Kupolaste završetke kula nalazimo na Kapetanovoj kuli u Zadru, glavnoj kuli kaštela Kamerlengo u Trogiru, Kegaljgradu i Kličevici.

44 Takva visina bedema nije neuobičajena na hrvatskom prostoru. Nalazimo je, primjerice, na bedemima Hreljina koji su izvorno bili visoki oko $3 \mathrm{~m}$, uključujući i prsobran s kruništem, omiškoj tvrđavi Starigrad, kao i na Garić-gradu na Moslavini. Vanja Kovačić, Omiška tvrđava Starigrad, Prilozi povijesti umjetnosti u Dalmaciji, go. 25, br. 1, Split, 1985., 161 - 177; Zorislav Horvat, Zidine i braništana utvrdama kontinentalne Hrvatske, Prostor, br. 2, Zagreb, 1996., $184-185$, sl. 14; K. Regan, Plemićki grad Garić, 15 - 62. 
Poput vanjskog plašta jezgre, kula je bila zidana od rustičnije priklesana kamena kvadratnog formata slaganim u pravilno uslojene redove različitih visina, što znači da ju je sagradio Nelipac II. Nelipić prigodom obnove utvrde tijekom prve polovice XIV. st. Ulaz u nju nalazio se na sjeveroistočnom bedemu. Od ostalih detalja na kuli danas nam je poznat tek jedan prozor vidljiv u gornjoj zoni jugozapadnog bedema na crtežu Kamička iz XIX. st.

Od nekadašnjeg jugoistočnog bedema utvrđenog dvorišta danas su se očuvala tek četiri manja fragmenta u visini temelja. $S$ obzirom na to da se tri od njih pružaju pravcem sjeverozapad-jugoistok, a samo jedan smjerom sjeveroistok-jugozapad, vrlo je izgledno da je unutarnje dvorište na dva mjesta bilo poprečno pregrađeno. No ne radi obrane, premda ni tu mogućnost ne smijemo odbaciti, već iz potrebe poravnavanja relativno strmog dvorišta kako bi se u njemu stvorilo dovoljno prostora za podizanje gospodarskih građevina, poput kuhinje, kovačnice i sl. S obzirom na izuzetnu skučenost dvorišta predgrađa, dio gospodarskih građevina ove utvrde svakako je bio i na zaravnjenom prostoru ispred utvrde, neposredno uz početak pristupne staze.

Sudeći prema Paganovu crtežu i konfiguraciji terena, moguće je da je pristup utvrđenom predgrađu bio zapriječen još jednim manjim bedemom s vratima. Mada se danas na pristupnoj stazi ne prepoznaju njegove strukture, njegovo postojanje možemo pretpostaviti na samom početku pristupne staze, neposredno ispod jugoistočnih bedema jezgre. ${ }^{45}$

\section{ZAKLJUČAK}

Premda se iz današnjih ostataka ne može precizno odrediti izgled Kamičca prije njegove propasti, na osnovi vidljivih ostataka te arhivske i slikovne građe ipak ga možemo opisati kao malen i tlocrtno jednostavan obrambeni srednjovjekovni kompleks - tvrdi grad (castrum) longitudinalnog ili izduženog tlocrta, koji se sastojao od male romaničke jezgre poligonalne osnove na sjeveroistočnoj polovici utvrde te utvrđenog dvorišta s kulom na jugozapadnoj

45 Slične obrambene strukture nalazimo na nizu drugih srednjovjekovnih utvrda. U Hrvatskoj ga vidimo kod Okića na Samoborskom gorju, Starigradu kraj Senja, u susjednoj Bosni na utvrdama Visoko i Kozograd, dok je možda najljepši primjer utvrda Karlštejn u Češkoj, gdje su svojevremeno postojale čak dvije takve strukture. Podizanjem takvih bedema jednostavno se htjelo u slučaju opsade otežati neprijateljskim vojnicima pristup podnožju bedema glavne utvrde. Đoko MAZALIć, Visoki, bosanski grad srednjeg vijeka, Glasnik zemaljskog muzeja u Sarajevu. Nova serija, sv. 9, Sarajevo, 1954., 227 - 253; Vlasta DvořÁkovÁ, Dobroslava Menclové, Karlštejn, Praha, 1965., 9; Enver Im amović, Kozograd kraj Fojnice, Arheološki pregled, sv. 24, Beograd, 1985., 150 - 151. 
polovici utvrde. Sama jezgra bila je podignuta na najvišem položaju utvrde zbog čega je ona ostavljala dojam još višeg kompleksa nego što je bila.

Mada bez čišćenja terena te barem u dijelovima nužnog arheološkog iskopavanja danas nije moguće izraditi njegovu točniju i potpuniju sliku, kombinacijom postojeće tlocrtne situacije $s$ povijesnim opisima, crtežima i planovima, rekonstrukcijom smjera pružanja pojedinih zidova logikom gradnje i konfiguracije terena, analogijama te analizom strukture zidova možemo u izvjesnoj mjeri riješiti problem podrijetla njegovih pojedinih cjelina i u grubo rekonstruirati razvoj ove utvrde kroz najmanje dvije faze.

Kao što je to slučaj za većinu srodnih građevinskih kompleksa, nemamo podataka o utemeljenju Kamičca. No ono što je sigurno jest da je postojao prije polovice XIV. st. kada se prvi put spominje. Od te njegove prve faze očuvali su se tek skromni ostatci utvrđenog palasa na najvišoj točki utvrde, koji je vrlo vjerojatno podignut najkasnije tijekom druge polovice XIII. st., a moguće još i ranije. Mada su se njegove građevinske strukture sačuvale tek u temeljima, one su u dovoljnoj mjeri vidljive da na osnovi njihova tlocrta, smještaju u prostoru i vrsti terena prvobitni Kamičac svrstavamo u skupinu romaničkih visinskih tvrdih gradova, sagrađenih na kamenim vrhovima stožastog oblika tijekom XIII. i XIV. st. u razdoblju romanike.

Drugoj razvojnoj fazi Kamičca vrlo vjerojatno pripadaju sve danas vidljive građevinske strukture koje su, sudeći prema izgledu pročelja i Ludovikovoj ispravi iz 1345. godine, sagrađene tijekom prve polovice XIV. st. za gospodstva Nelipca II. Nelipića, odnosno u vrijeme kada je ovaj hrvatski velikaš nakon pada Bribirskih knezova 1322. godine bio na vrhuncu svoje političke, vojne i gospodarske moći.

Vrlo je izgledno da je u ovoj građevinskoj fazi došlo do značajne pregradnje i nadogradnje jezgre, ali i do povećanja čitave površine utvrde podizanjem utvrđenog predgrađa. Strme litice glavice brda na kojem je stajao palas obzidane su novim bedemima što je znatno povećalo površinu jezgre i omogućilo stvaranje manjeg unutrašnjeg dvorišta u kojem se morala nalaziti i cisterna. $U$ isto je vrijeme $s$ jugozapadne strane jezgre, na nekadašnjem pristupnom hrptu, podignuto utvrđeno predgrađe. Njegovu glavnu okosnicu činio je jugoistočni bedem te manja četverokutna kula na jugozapadnom rubu utvrde. $S$ jedne strane ona je pružala bolju zaštitu novim ulaznim vratima $u$ kompleks, a s druge strane s nje se mogao vršiti nadzor kretanja brodova samom rijekom od Visovca do Roškog slapa. Zasigurno se u njoj nalazio smještaj za vojnu posadu utvrde s obzirom na to da u samoj jezgri nije bilo dovoljno mjesta za njih. Možemo pretpostaviti da bi ovoj građevinskoj fazi mogao pripadati 
danas nestali manji bedem, koji Pagano crta neposredno ispod jugoistočne strane jezgre, na mjestu gdje uz jugoistočne litice započinje strmi uspon prema glavnom ulazu u Kamičac.

U takvom obliku mogao je Kamičac dočekati svoj kraj, koji je nastupio osmanskim osvajanjem 1522. ili 1523. godine. Razloge njegova napuštanja možemo tražiti u njegovoj skučenosti i neprilagođenosti ratovanju vatrenim oružjem, a s druge strane u lošem geostrateškom položaju u novoj državi jerse nakon pada Skradina našao duboko u osmanskom zaleđu zbog čega nije postojala potreba za jačom vojnom nazočnošću u njemu. 


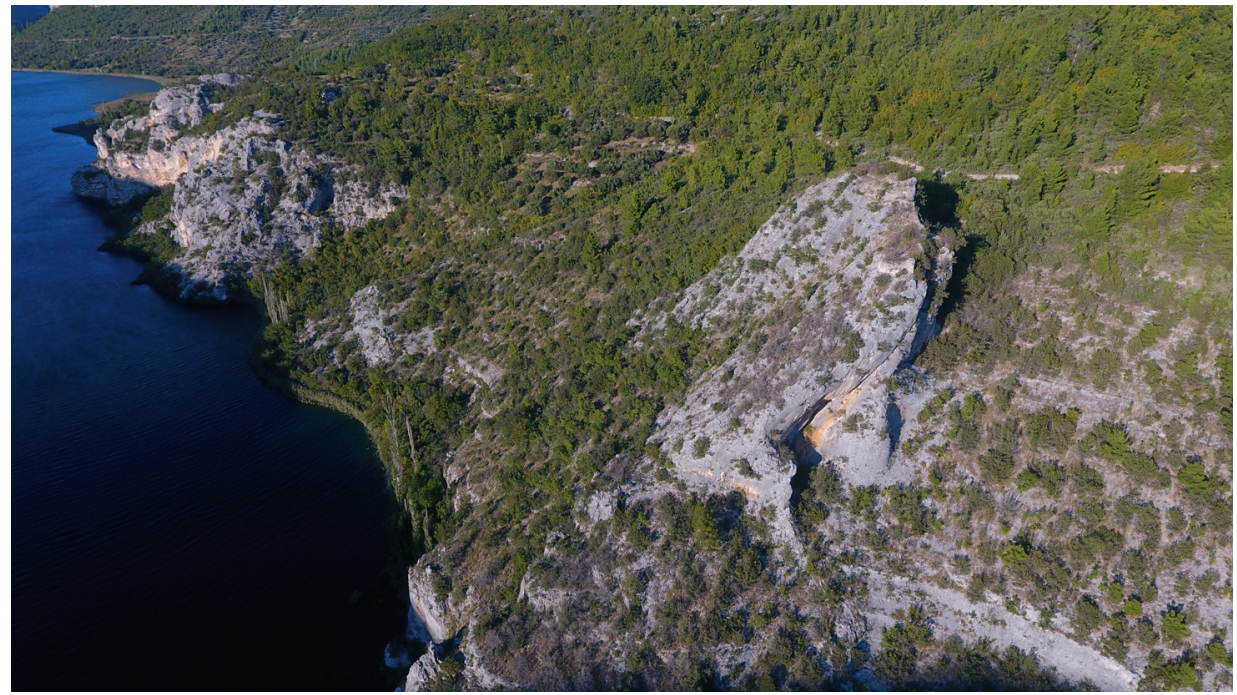

SLIKA 1. Kamičac gledan sa zapada (foto D. Lovrić, 2019.)

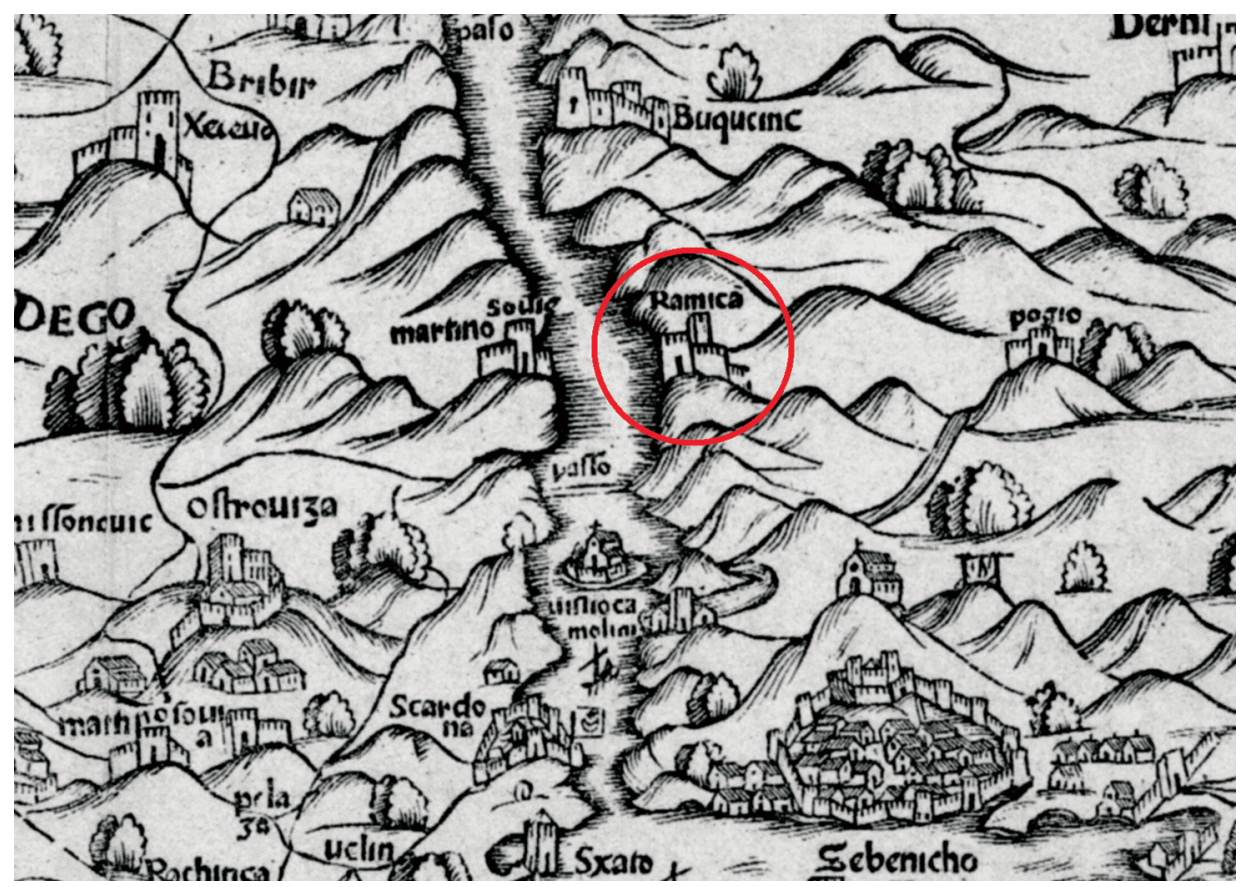

SLIKA 2. Kamičac na zemljovidu Matea Pagana, 1522. (https://digitalna.nsk.hr/pb/?object $=$ info\&id $=10182$ ) 


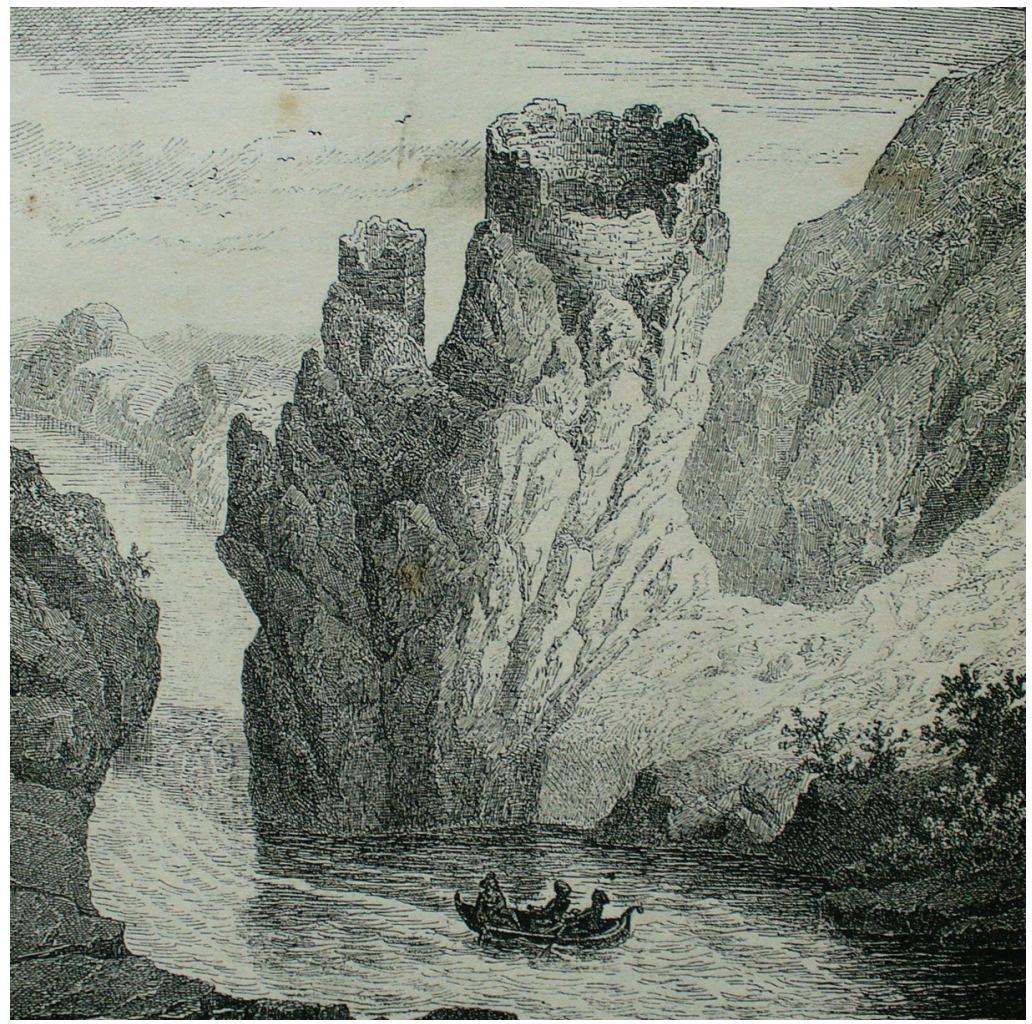

SLIKA 3. Crtež Kamičca prije 1880. (Rad JAZU, sv. 53, Zagreb, 1880., 10)

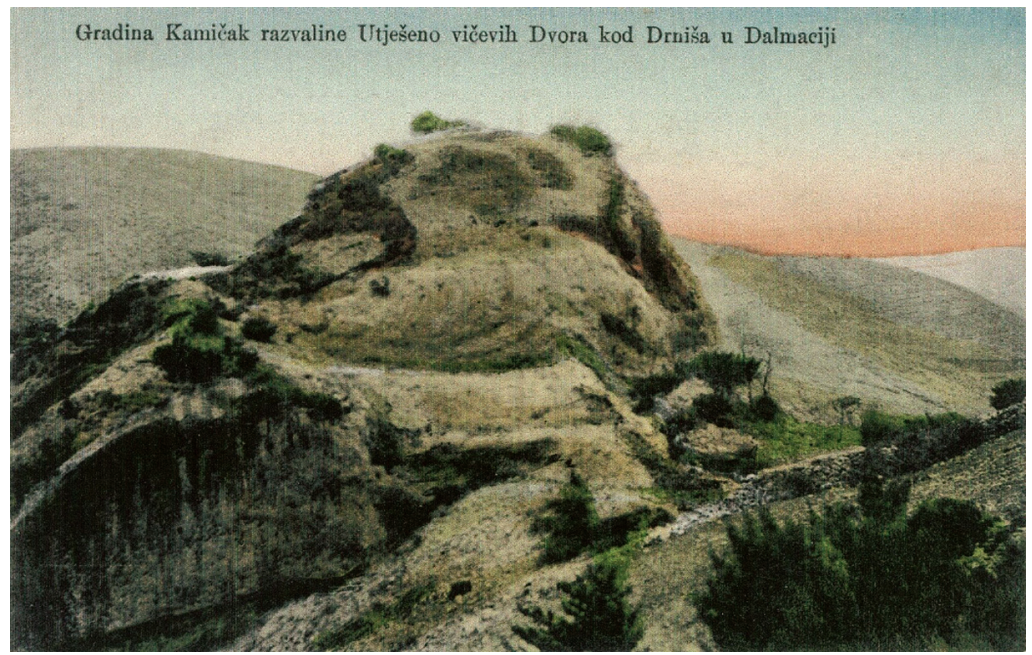

SLIKA 4. Kamičac gledan s jugoistoka - kolorirana razglednica s početka XX. st. (https://digitalna.nsk.hr/pb/?object=info\&id=573557) 


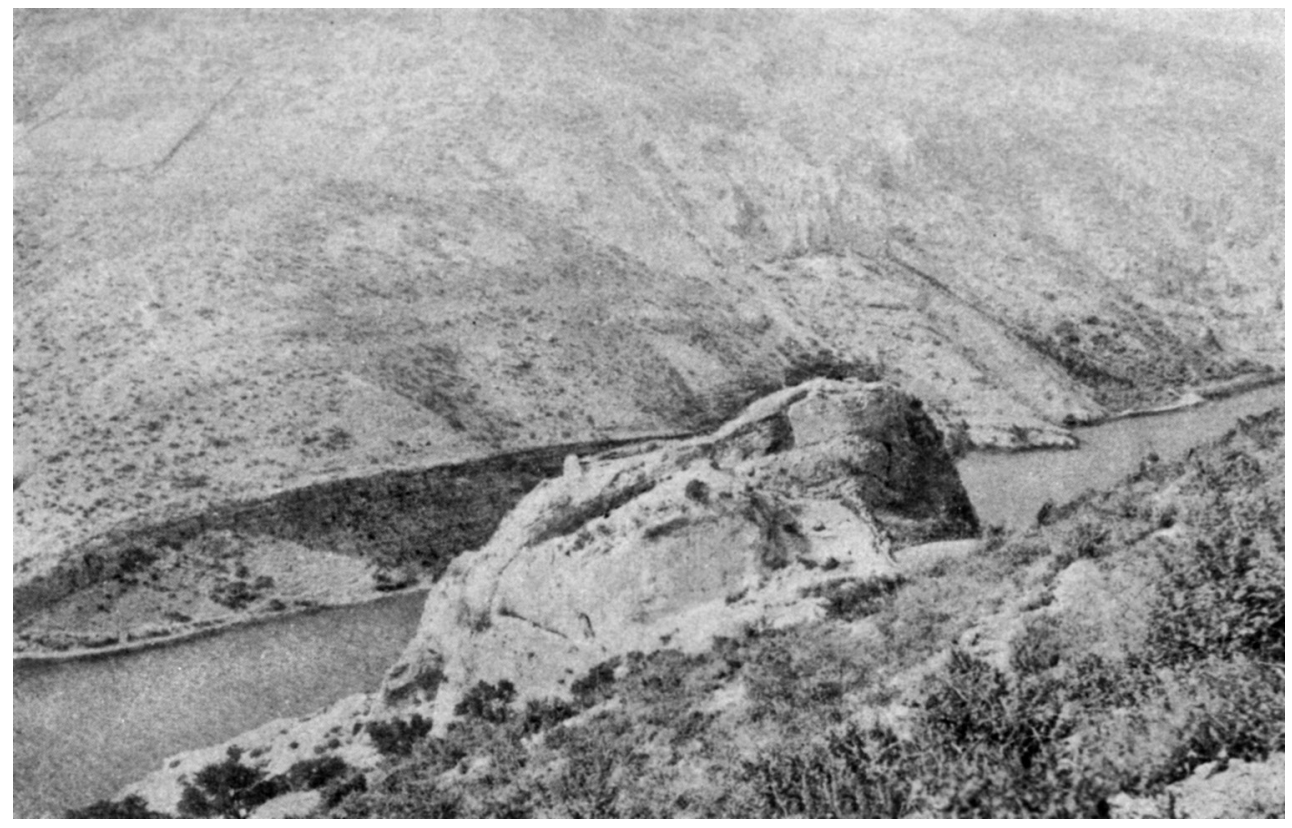

SLIKA 5. Kamičac gledan s juga s početka XX. st. (S. Gunjača, Ispravci i dopune, 27, s1. 3)

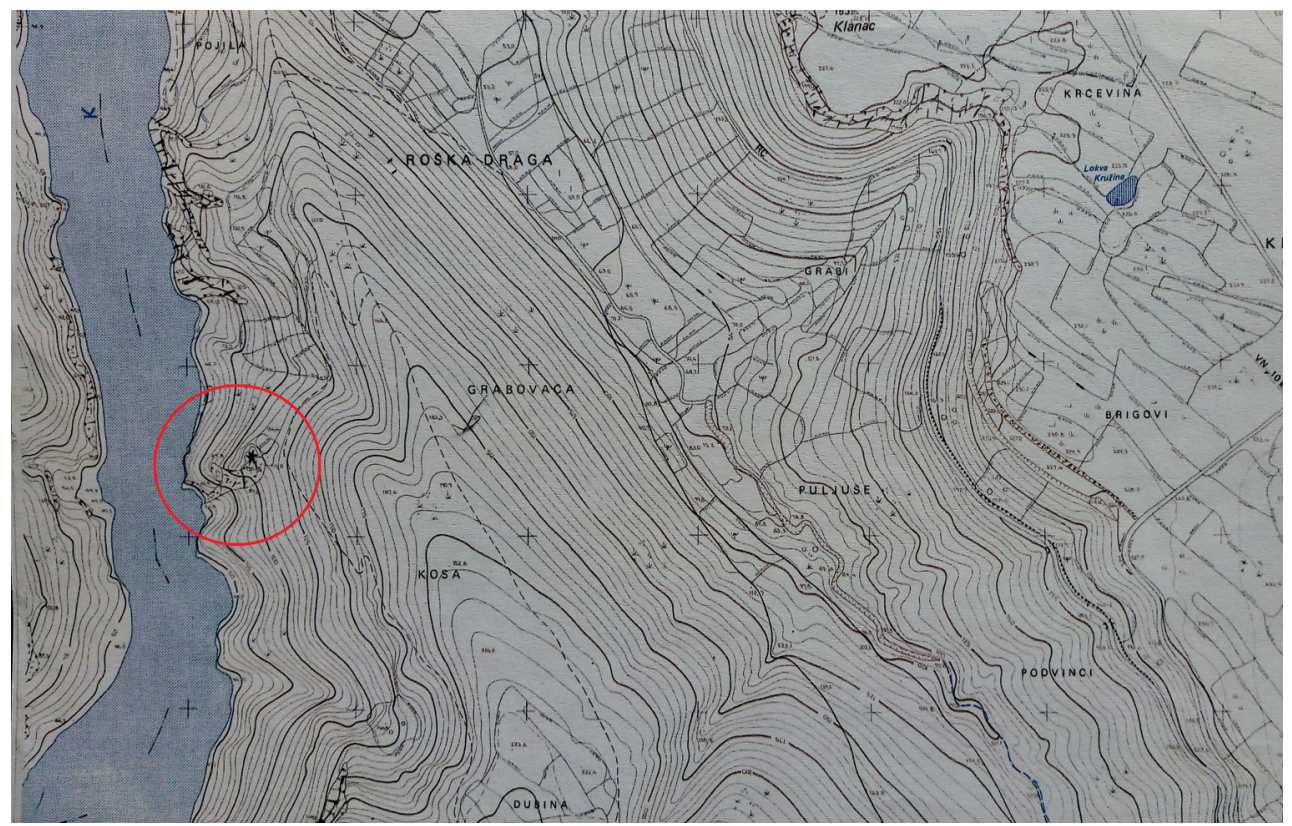

SLIKA 6. Temeljna državna karta - isječak (Geoportal) 


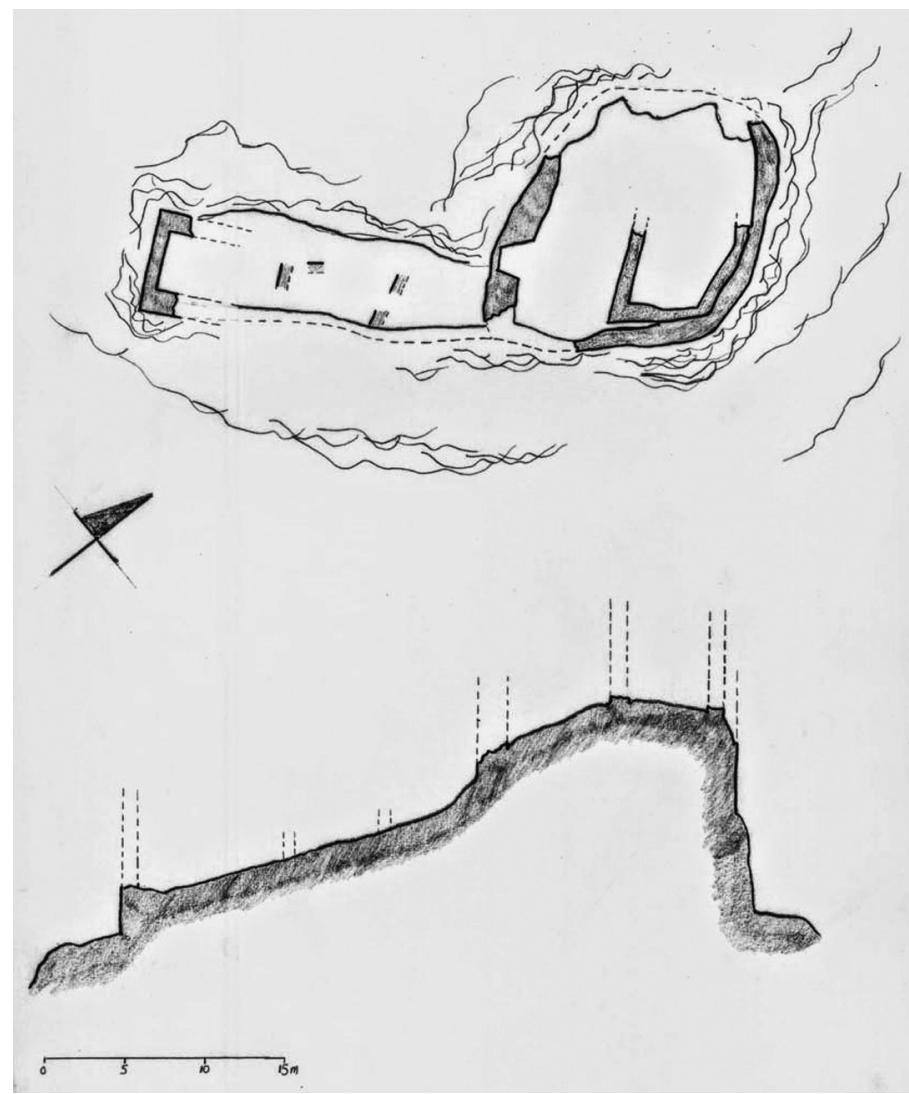

SLIKA 7. Kamičac, skica tlocrta i presjek prema današnjim ostatcima (foto K. Regan, 2019.)

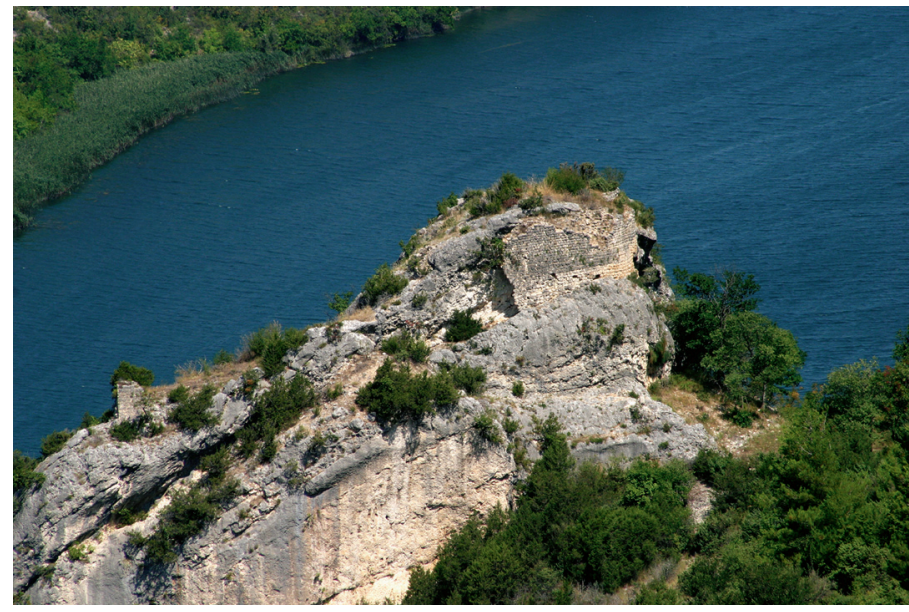

SLIKA 8. Kamičac gledan s juga (foto Z. Tanocki, 2015.) 


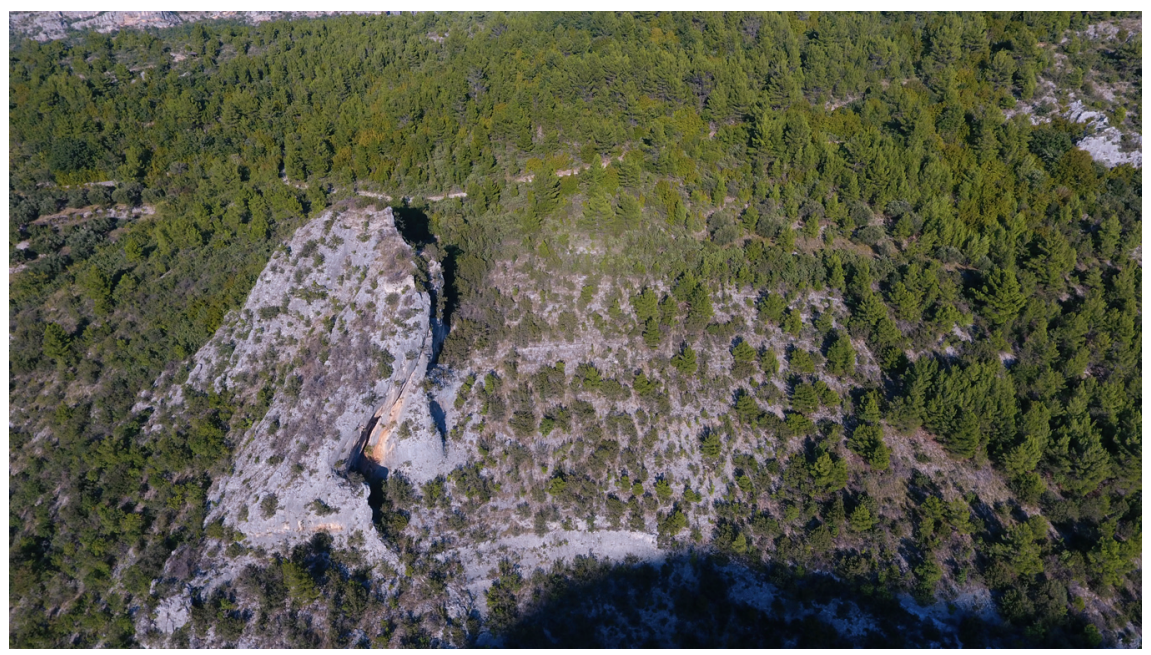

SLIKA 9. Kamičac gledan s jugozapada (foto D. Lovrić, 2019.)

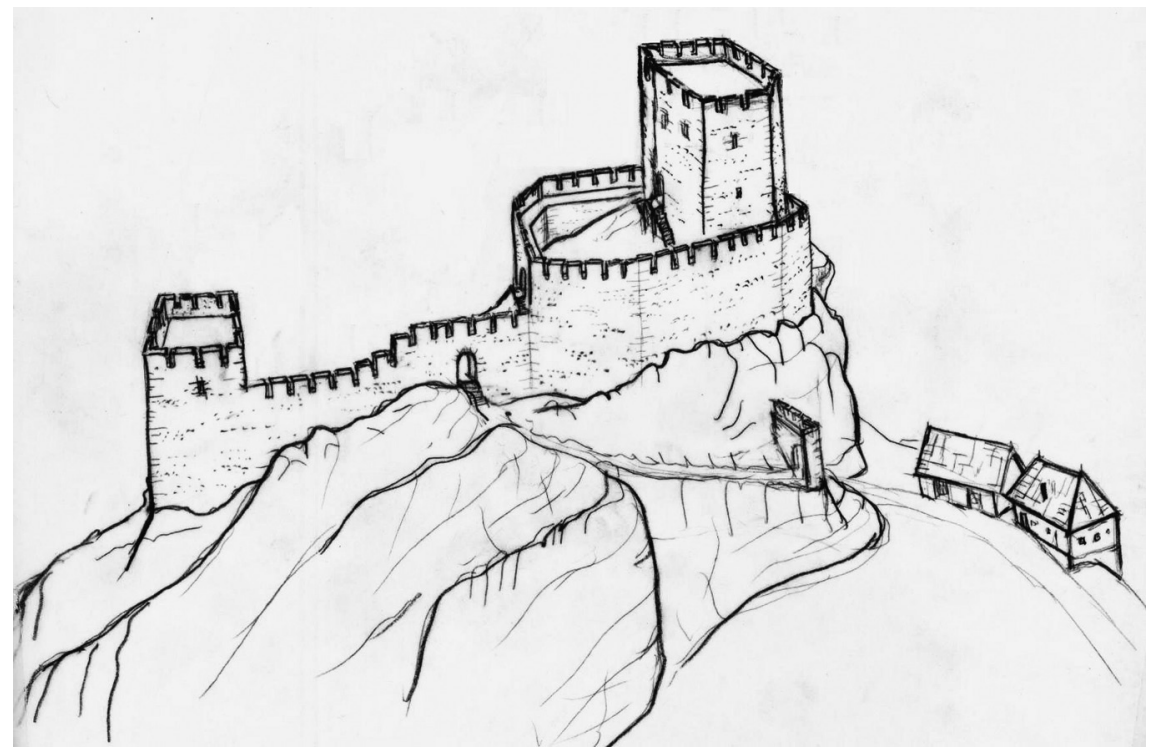

SLIKA 10. Kamičac, hipotetska rekonstrukcija izgleda utvrde u posljednjoj fazi razvoja (foto K. Regan, 2019.) 


\section{IZVORI I LITERATURA}

\section{OBJAVLJENI IZVORI:}

Gortan Veljko, Glavičić Branimir, Vratović Vladimir, Kurelac Miroslav, KARBIĆ Damir, LAdIć Zoran, Obsidio iadrensis/Opsada Zadra, Zagreb, 2007.

Ivšić Stjepan, BRATulić Josip, LAdić Zoran, Acta croatica, Zagreb, 2017.

LJUBić, Šime, Listine o odnošajih izmedju južnoga slavenstva i Mletačke Republike, Knj. I-X, Zagreb, 1868. -1891.

MÁLYUSZ, Eleméretal., Zsigmondkori oklevéltár, vol. I-X, Budapest, 1951. - 2007. NAGY, Imre, Anjoukori okmánytár. Codex diplomaticus Hungaricus Andegavensis. I. (1301-1321), vol. I-XL, Budapest, 1878. -2014.

Smičinlas, Tadija et. al, Codex diplomaticus Regni Croatiae, Dalmatiae et Slavoniae. Diplomatički zbornik Kraljevine Hrvatske, Dalmacije i Slavonije, Vol. I-XVIII, Zagreb, 1904. -1990.

Thallóczy, Lajos, BArbáAs, Samu, A Frangepán csalad okleveltara. Codex diplomaticus comitum de Frangepanibus, Budapest, 1910.

Wenzel, Gusztáv, Árpádkori új okmánytár. Codex diplomaticus Arpadianus continuatus. Budapest, Vol. I-XII, Pest, 1860. - 1874.

\section{LITERATURA:}

Antoljak, Stjepan, Balassa, Franjo de Gyarmáth, Hrvatski biografski leksikon, 1., Zagreb 1983., 382.

BAČıĆ, O. Petar K., Grad Kamičak na Krci, Jadranska vila, god. 2, br. 7, Split, 1923., $105-106$.

BAČIĆ, O. Petar K., Grad Kamičak na Krci, Jadranska vila, god. 2, br. 8, Split, 1923., $118-120$.

BAčıć, O. Petar K., Grad Kamičak na Krci, Jadranska vila, god. 2, br. 9, Split, 1923., $135-151$.

BAČıć, O. Petar K., Grad Kamičak na Krci, Jadranska vila, god. 2, br. 10, Split, 1923.,151 - 153.

BAČIć, O. Petar K., Grad Kamičak na Krci, Jadranska vila, god. 2, br. 11, Split, 1923., $167-171$.

BAčıć, O. Petar K., Grad Kamičak na Krci, Jadranska vila, god. 2, br. 12, Split, 1923., $184-187$.

BIrIN, Ante, Knez Nelipac i hrvatski velikaški rod Nelipčića, doktorski rad, Filozofski fakultet Sveučilišta u Zagrebu, Zagreb, 2006. 
BIRIN, Ante, Posjedi Nelipčića na području srednjovjekovnog kotara Promine, Miljevci u prošlosti (s pogledom u budućnost) Zbornik radova sa znanstvenog skupa Miljevci u prošlosti (s pogledom u budućnost), ur. Marko Menđušić i Drago Marguš, Visovac-Drinovci, 2008., 117- 128

Blagec, Ozren, Slavonski i hrvatski sabori u Križevcima, Cris, god. 14, br. 1, Križevci, 2012., $365-373$.

Bogović, Mile, Andrija, Hrvatski biografski leksikon, br. 1, Zagreb, 1983., 138 139.

BoticA, Ivan, Krbavski knezovi u srednjem vijeku, doktorski rad, Zagreb, 2011. Ćuzela, Josip, Šibenski fortifikacijski sustav, Šibenik, 2005.

DeAnović, Ana, Glosar naziva u upotrebi srednjovjekovnog i renesansnog vojnog graditeljstva u Hrvatskoj, Utvrde i perivoji, Zagreb, 2001., 79 - 96.

Dvoř́́ Ková, Vlasta, MEnclová, Dobroslava, Karlštejn, Praha, 1965.

FÜGEDI, Eric, Castles and society in medieval Hungary (1000-1437), Budapest, 1986.

GudelJ, Ljubomir, Čačvina utvrda, Split-Trilj, 2006.

GunJAČA, Stipe, Tiniensia archaeologica-historica-topographica, Starobrvatska prosvjeta, III. serija, br. 7, Split, 1960., 7 - 142.

GuNJAČA Stjepan, Ispravci i dopune starijoj hrvatskoj historiji, sv. 4, Zagreb, 1978.

Hilje, Emil, Gradnja kaštela u Ražancu 1507. godine, Radovi Zavoda za povijesne znanosti u HAZU u Zadru, br. 50, Zadar, 2008., 119 - 145.

Hilje, Emil, Mletački kaštel u Zadru, Ars Adriatica, br. 1, Zadar, 2011., 109 - 116. Horvat, Anđela, grad (burg), Enciklopedija Jugoslavije, 3, Zagreb, 1958., 525 -531. HoRvat, Zorislav, O izgledu srednjovjekovnoga zida na primjerima nekih građevina u kontinentalnoj Hrvatskoj, Godišnjak zaštite spomenika kulture Hrvatske, sv. 12, Zagreb, 1986., 176 - 192.

HoRvat, Zorislav, Zidine i braništa na utvrdama kontinentalne Hrvatske, Prostor, br. 2, Zagreb, 1996., 175 - 200.

Horvat, Zorislav, Katedrala Sv. Jakova u Krbavi kraj Udbine, u: Krbavska bitka i njezine posljedice (Zbornik radova), Zagreb, 1997., 130 - 158.

Horvat, Zorislav, Ulazi u burgove 12-15. stoljeća, Prostor, god. 6, sv. 1-2, Zagreb, 1998., $41-66$.

Horvat, Zorislav, TkAlčec Tatjana, Arhitektura i arhitektonska plastika burga Vrbovca kraj Huma na Sutli, Prilozi Instituta za arbeologiju u Zagrebu, sv. 1, Zagreb, 2010., $181-218$.

Horvat, Zorislav, Burgologija - Srednjovjekovni utvrdeni gradovi kontinentalne Hrvatske, Zagreb, 2014. 
Hunyadi, Zsolt, Hospitallers in the medieval Kingdom of Hungary, c. 1150-1387. (A Dissertation). Budapest, 2004.

HunYaDI, Zsolt, The formation of the territorial structure of the Templars and Hospitallers in the medieval Kingdom of Hungary. U: Die geistlichen Ritterorden in Mitteleuropa. Mittelalter, Brno, 2011., 183 - 197.

Imamović, Enver, Kozograd kraj Fojnice, Arheološki pregled, sv. 24, Beograd, 1985., $150-151$.

JA KšIĆ, Nikola, Iz srednjovjekovne topografije Knina, Radovi Filozofskog fakulteta u Zadru, br. 20(9), Zadar, 1980. - 1981., 43 - 52.

JA KŠIĆ, Nikola, Prilozi urbanizmu srednjovjekovnog Knina, Izdanja HAD-a, br. 15, Zagreb, 1990., 122 - 130.

Juran, Kristijan, Barzman, Karen-Edis, FaričIć, Josip, Kartografija u službi mletačke države: karta sjeverne i srednje Dalmacije nepoznatog autora s početka 16. stoljeća, Geoadria, 24 (2019) 2., 93 - 139.

JuRIĆ, Ante, Gradovi, utvrde i sakralni spomenici uz Krku i Čikolu, Skradin, 2004.

JURKović, Ivan, Osmanska ugroza, plemeniti raseljenici i hrvatski identitet, Povijesni prilozi, br. 31, Zagreb, 2006., 39 - 69.

Jurković, Ivan, Povijest Hrvata, knj. III, Zagreb, 2019.

Karbić, Damir, Povijesni podaci o burgu Vrbovcu, u: Tatjana TkalčEc, Burg Vrbovec u Klenovcu Humskome, Zagreb, 2010., 202 - 222.

Kekez, Hrvoje, Škarpa Durbeta, Daria, Čı kara, Duško, Ćurić, Anka, Povijesna studija o razvoju kninske tvrđave, u: Knin. Kninska tvrdava. Konzervatorski elaborat, Zagreb, 2018., digitalno izdanje, https://www.knin. $\mathrm{hr} / \mathrm{wp}$-content/uploads/2019/02/Kninska-tvrdava-Elaborat_ispravak.pdf, posjećeno 18. 6. 2020.

KolARIĆ, Aleksandar, Juraj Utješinović i njegovo doba, Zbornik odsjeka za povijesne znanosti Zavoda za povijesne i društvene znanosti HAZU, sv. 16, Zagreb, 1998., 119 - 133.

Kovačıć, Vanja, Omiška tvrđava Starigrad, Prilozi povijesti umjetnosti u Dalmaciji, god. 25, br. 1, Split, 1985., 161 - 177.

Kunuljević SaKcins Ki, Ivan, Priorat Vranski sa vitezi templari $i$ hospitalci sv. Ivana u Hrvatskoj. Povijesna rasprava (rukopis), Zagreb, 1885.

LAszowski, Emil, Prilog historiji hrvatskih porodica Martinuševića, Utješinovića, Mišljenovića i njihovih srodnika, Vjesnik Kr. državnog arkiva u Zagrebu, br. 7, Zagreb, 1937., 153 - 157.

Lovrenović, Dubravko, Na klizištu povijesti, Zagreb-Sarajevo, 2006. 
MAgAš, Damir, Geografske odrednice nastanka karte Matea Pagana: Cijeli okrug Zadra i Šibenika (Tutto el Contado di Zara et Sebenicho), u: Triplex Confinium (1500.-1800.): ekohistorija: zbornik radova $s$ medunarodnog znanstvenog skupa, ur. D. Roksandić, Split, Zagreb, 2003., 13 - 28.

MARKOVIĆ, Mirko, Descriptio Croatiae. Hrvatske zemlje na geografskim kartama od najstarijih vremena do pojave topografskih karata, Zagreb, 1993.

MazAlić, Đoko, Visoki, bosanski grad srednjeg vijeka, Glasnik zemaljskog muzeja u Sarajevu. Nova serija, sv. 9, Sarajevo, 1954., 227 - 253.

Mužıć, Ivan (priređivač), Vlasi u hrvatskoj historiografiji, Split, 2010.

Ninić, Marina, Obad Šćitaroci, Bojana, Krajnik, Damir, Srednjovjekovne utvrde na području Nacionalnog parka Krka, Prostor, god. 20, sv. 2, Zagreb, 2012., 393 - 401.

PAIĆ, Paško, Hrvatski kraljevski grad Knin, Šibenik, 1998.

Petricioli, Ivo, Novi rezultati u istraživanju zadarskih srednjovjekovnih fortifikacija, Diadora, sv. 3, Zadar, 1965., 169 - 204.

Petricioli, Ivo, Zoranićeve deželije na jednoj suvremenoj karti, Zadarska revija, br. 5, Zadar, 1969., 523 - 529.

Petricioli, Ivo, Stari Zadar u slici i riječi, Zadar, 1999.

Raukar, Tomislav, Petricioli, Ivo, Švelec, Franjo, Peričić, Šime, Zadar pod mletačkom upravom, Zadar, 1987.

Regan, Krešimir, Utvrda Sv. Jurja u Caski na otoku Pagu, Prilozi Instituta ta arheologiju u Zagrebu, sv. 19, Zagreb, 2002., 141 - 148.

REgAn, Krešimir, Plemićki grad Garić, Radovi Zavoda za znanstvenoistraživački i umjetnički rad u Bjelovaru, sv. 4, Bjelovar, 2011., 15 - 62.

Regan, Krešimir, Plemićki grad Kegalj (Kegaljgrad), Radovi Zavoda za povijesne znanosti HAZU u Zadru, sv. 54, Zadar, 2012., 1 - 34.

Regan, Krešimir, Gornji grad kninske tvrđave, u: Ascendere historiam. Zbornik $u$ čast Milana Krubeka, ur. Marija Karbić i ostali, Zagreb, 2014., 463 - 495.

Regan, Krešimir, Plemićki grad Vrana, u: Braća Vranjani i vransko područje tijekom povijesti, Zbornik radova, ur: Božo Došen, Zadar, 2017., 313 - 360.

Regan, Krešimir, Dugački, Vlatka, Rod Talovaca ili Talovačkih i njihova ostavština u Bjelovarsko-bilogorskoj županiji, Radovi Zavoda za znanstvenoistraživački i umjetnički rad u Bjelovaru, sv. 12, Bjelovar, 2018., $139-157$.

Slukan Altić, Mirela, Kartografski izvori za povijest Triplex Confiniuma, Zagreb, 1999.

Slukan Altić, Mirela, Razvoj gradova oko rijeke Krke, Grada $i$ prilozi za povijest Dalmacije, sv. 21, Split, 2006., 207 - 248. 
Slukan Altić, Mirela, Povijesna geografija rijeke Krke. Kartografska svjedočanstva, Šibenik, 2007.

Slukan Altić, Mirela, Krka kao razdjelnica velikaških gradova Šubića i Nelipića na karti Matea Pagana nastaloj oko 1522. godine, Ekonomska $i$ ekobistorija. Časopis za gospodarsku povijest i povijest okoliša, br. 3, Zagreb, 2007., $51-61$.

Slukan, Mirela, Kartografski izvori za povijest Triplex Confiniuma, Zagreb, 1999.

Slukan Altić, Mirela, Povijesna geografija rijeke Krke - Kartografska svjedoćanstva, Zagreb, 2007.

Smiljanić, Franjo, Nastanak i razvoj srednjovjekovnog Knina, Radovi Filozofskog fakulteta u Zadru, br. 24(11), Zadar, 1984. - 1985., 119 - 132.

Stošı́́, Krsto, Rijeka krka sa 54 slike. Priredio i popratnu studiju napisao Drago Marguš, Šibenik, 2012.

ST RČIĆ, Petar, Frankapan, Ivan VI. st., Hrvatski biografski leksikon, sv. 4, Zagreb, 1998., $410-411$.

ŠımeK, Marina, Utvrda Paka, Hrvatski arheološki godišnjak, sv. 4, Zagreb, 2007., $161-163$.

Zaninović, Joško, Gaurina, Davor, Nelipićeve utvrde na rijekama Krki i Čikoli, Zbornik radova sa znanstvenog skupa Miljevci u prošlosti (s pogledom u budućnost), ur. Marko Menđušić i Drago Marguš, Visovac-Drinovci, 2008., $145-162$.

ZEKAN, Mate, Srednjovjekovne utvrde na rijeci Krki, Visovački zbornik, Visovac, 1997., 391 - 405.

ZEKAN, Mate, Utvrđeni gradovi i kule na rijeci Krki, Dalmatinska zagora nepoznata zemlja (katalog izložbe), Zagreb, 2007., 637 - 641.

Zlatović, Stipan, Topografičke crtice o starohrvatskim županijama u Dalmaciji i starim gradovima na kopnu od Velebita do Neretve, Starohrvatska prosvjeta, god. 2, sv. 3, Knin, 1896., $148-155$.

\section{INTERNET IZVORI:}

Gradina Kamičak: razvaline Utješinovićevih Dvora kod Drniša u Dalmaciji, Nacionalna i sveučilišna knjižnica u Zagrebu, https://digitalna.nsk.hr/ $\mathrm{pb} /$ ?object=info\&id=573557, posjećeno 29. 9. 2019.

https://hungaricana.hu/en/, posjećeno 18.6.2019.

https://digitalna.nsk.hr/pb/ ?object=view\&id=10182\&tify $=\{\% 22$ pages $\% 22:[1$

],\%22view\%22:\%22scan\%22\}, posjećeno 18.6. 2019. 
http://www.felbar.com/hr/map/autors/a-e/page/6/view/19/, posjećeno 18. 6. 2019.

https://geoportal.dgu.hr/, posjećeno 18.6.2019.

Nacionalna i sveučilišna knjižnica u Zagrebu, Zbirka Novak u Zbirci zemljovida i atlasa NSK, https://digitalna.nsk.hr/pb/?object=view\&id=10182\&tify $=\{\%$ 22pages\%22:[1],\%22view\%22:\%22scan\%22\}, posjećeno 29. 9. 2019. 


\section{Krešimir REGAN}

\section{THE STRONGHOLD (CASTRUM) OF KAMIČAC}

\section{SUMMARY}

The remains of the town of Kamičac are located on a steep stone hill that rises almost vertically above the left bank of the river Krka, in the canyon Med gredama between Roški slap and Visovačko Lake. In the documents, it was first mentioned in 1345 as a newly built hillfort of the noblemen Nelipić at the place of their older 13th-century fortress. After the death of Nelipać II, Nelipić's management of the hillfort was taken over by a collateral line of Izan's family. When Nelipac of Nečven, the last male descendant of Izan's line, died in 1396, all the family estates along the Krka river, including Kamičac, were taken over by the Cetina prince Ivaniš Nelipić. He held them until he died in 1435 . Kamičac and other family estates were supposed to belong to the crown at that time because Ivaniš died without a male heir. However, his daughter Katarina, the wife of Ivan VI. Senior Frankopan, refused to return her father's property.

For this reason, the Hungarian-Croatian king Sigismund of Luxembourg declared Catherine and Ivan rebels and sent an army against them under the leadership of the Talovac or Talovački brothers, who defeated them militarily by the beginning of 1437. In that conflict, the Talovac brothers, among other things, captured Kamičac, which they soon ceded to the aristocrat Martinušićs family on the king's orders. This fort was in their hands only until 1445, when as a dowry it passed into the possession of the noble family Utišenić of the Lapčani lineage. Their descendants then held Kamičac until 1490, when the Hlapčić brothers were mentioned as itsnewmasters. In unknown circumstances, they were soon replaced as new owners by the Mišljenovićes of the Kolunić lineage. They held Kamičac until 1522 or 1523 when it was conquered by the Ottomans and left to the ravages of time. At the beginning of the 19th century, its ruins looked striking, but they were soon dismantled by the local population, which is why only modest remains have been preserved to this day. Nevertheless, based on them and the archival and graphic material, we can still describe it as a small and straightforward defensive medieval complex. It was a stronghold (castrum) with a longitudinal or elongated ground plan, consisting of a small Romanesque nucleus of a polygonal base with a fortified palas tower in the northeast half of the fort and a fortified suburbum with a tower on the south-western half of the fort.

Keywords: the stronghold of Kamičac, (castrum), nobles Nelipićes, Martinušićes, Utišenićes, Mišljenovićes, the Krka river, 13th - 16th century. 